\title{
Mısır'da Piramitlerden Mezar Evlere
}

\section{From Pyramids to Burial Houses in Egypt}

\author{
Aynur ERYiĞiT BADER \\ Dr., Dinler Tarihi Anabilim Dalı, Emekli Öğretmen \\ PhD., Department of History of Religions, Retired Teacher \\ Zonguldak/Turkey \\ sahranurbader@gmail.com \\ orcid.org/0000-0002-2902-5397
}

\author{
Makale Bilgisi / Article Information \\ Makale Türü / Article Types : : Araştırma Makalesi / Research Article \\ Geliş Tarihi / Received : : 14 Ekim / October 2020 \\ Kabul Tarihi / Accepted $\quad$ :05 Kasım / November 2020 \\ Yayın Tarihi / Published : : 15 Aralık / December 2020 \\ Yayın Sezonu / Pub Date Season : Aralık / December \\ Cilt / Volume: 7 - Sayı / Issue: 2 - Sayfa / Pages: 581-610 \\ Atıf / Cite as \\ Eryiğit Bader, Aynur. "Mısır'da Piramitlerden Mezar Evlere". Bülent Ecevit Üniversitesi Ilahiyat Fakültesi Dergisi 7/2 \\ (2020), 581-610. \\ Doi: $10.33460 /$ beuifd. 810672 \\ İntihal / Plagiarism \\ Bu makale, en az iki hakem tarafından incelendi ve intihal içermediği teyit edildi. \\ This article has been reviewed by at least two referees and scanned via a plagiarism software. \\ Yayın Hakkı / Copyright ${ }^{\circ}$ \\ Zonguldak Bülent Ecevit Üniversitesi, İlahiyat Fakültesi tarafından yayınlanmıștır. Tüm hakları saklıdır. \\ Published by Zonguldak Bulent Ecevit University, Faculty of Theology, Zonguldak, Turkey. All rights reserved.
}

Öz: Illk insandan bu yana cesetler, gerek kokuşmasını önlemek, gerekse insana duyulan saygıdan dolayı bazı işlemlerden sonra mezarlara konulmaya başlanmıştır. Insan cesetlerinin konulduğu mezarlar tarih boyu milletlere ve inançlara göre birbirlerinden farklılık göstermiştir. Mezarlardan bazıları büyüklükleri ve gösterişli olmaları bakımından, anıt mezar olarak isimlendirilmiştir. Bunlar arasında çok önemli bir yere sahip olan Mısır'ın anıt mezarlarına piramit/haram denilmektedir. Piramitler arasında gerek görkemleri gerekse büyüklükleri ile en ilgi çekenleri firavun Kufu (خوفو), Hafra (خفرع) ve Menkaura (منكاور ع)'ya ait olanlardır. Bu piramitler dünya harikalarından sayılmaktadır. Bunlar bazı sırlarının hâlâ çözülememesi ile esrarengizliklerini korumaktadır. O günün şartlarında piramitlerin ve ölen kralların hizmetlerini yapan kişiler ve dini görevliler mezar yanında yapılan odalarda yaşarlardı. Bugün ise Mısır'da mezarlar, ev görünümüne sahip olup Kahire'de Müslümanlara ait olanların bir kısmında insanlar/aileler yaşamaktadır. Bu mezar evler, bazı kültürel, siyasi, ekonomik ve sosyal sebeplerden dolayı konut olarak tercih edilmekte ve buralarda yaşayanların sayısı milyonlarla ifade edilmektedir. Mezar evlerde iskan eden bu insanlar geçim, sağlık, eğitim, hijyen gibi pek çok problemle birlikte buralarda yaşamlarını sürdürmektedir. Böylece Mısır geçmişte yapılan büyüleyici ve esrarengiz anıt mezar/piramitleriyle, günümüzde de içerisinde yaşanılan mezar evle- 
riyle dikkat çekmektedir. Diğer taraftan Müslümanlar arasında bu şekilde defnedilmenin islam'a uygun olup olmadığı da tartışılmaktadır.

Anahtar Kelimeler: Mısır, Firavun, Mezar, Anıt Mezar, Piramit, Mezar Evler.

Abstract: Corpses have begun to be placed in graves after some procedures, both to prevent rotting and to respect people, since the first man. Graves where human corpses are placed have differed from each other according to nations and beliefs throughout history. Some of the tombs are named as monumental tombs in terms of their size and ostentation. Among these, the mausoleums of Egypt, which has a very important place, are called pyramid/haram. Among the pyramids, the most interesting with their magnificence and size are the those belonging to Pharaoh Kufu (خوف) , Hafra (خفرع) and Menkaura (منكاور ع). These pyramids are considered to be one of the wonders of the world. These remain mysterious, with some of their secrets still unsolved. Under the conditions of that day, people who served the pyramids and the deceased kings and religious officials lived in the rooms built next to the tomb. Today, the tombs have the appearance of houses and people/families live in some of those belonging to Muslims in Cairo. These grave houses are preferred as houses due to some cultural, political, economic and social reasons and the number of people living here is expressed in millions. These people dwelling living in grave houses continue their lives here with many problems such as livelihood, health, education and hygiene. Thus, Egypt attracts attention with its fascinating and mysterious monumental tombs / pyramids built in the past and the burial houses inhabited today. It is also discussed among Muslims whether such burials are suitable for Islam.

Keywords: Egypt, Pharaoh, Tomb, Monumental Tomb, Pyramid, Burial Houses,

\section{Giriş}

Mısır esrarengizliklerle dolu bir ülkedir. Bunlar arasında piramitler, mumyalar daima ilk akla gelenlerdendir. Mısır'daki piramitler, dünyadaki en önemli anıt mezarlardan olup sanatlı görkemlerinden dolayı arkeolojik eserlerden kabul edilir. Bunlar arasında özellikle Giza Piramitleri mimarinin zirvesi kabul edilir.

Bugün ise Mısır'da mezarlar yer altı odaları şeklinde olup üst kısımlarının yapılmasıyla evlere dönüştürülmekte ve buralarda aileler yaşamaktadır. Biz bu araştırmamızda piramitlerin oluşumu, mezarların ortaya çıkışı, Yahudilik, Hristiyanlık ve İslam mezar kültürüne değineceğiz; ancak mezar evlerde oturanlar Müslüman kesim olduğundan İslam'da mezar konusunu biraz daha geniş ele alacağız. Bunlarla birlikte Mısır'ın mezar evleri ve buralarda oturanların durumu ile ilgili geniş bilgi vermeye çalışacağız.

Araştırmamızda ana kaynakların yanı sıra kendi saha araştırma ve gözlemlerimizi aktaracağız. Çalışmamızın sonuna saha alanında çektiğimiz 
bazı resimleri ekleyerek konunun anlaşılmasına görsel katkı sağlamaya gayret edeceğiz.

\section{Mezar/Kabir, Piramit}

Mezar (مزار) , ziyaret edilen yer anlamında olup köken olarak Arapça bir kelimedir. Bu kelime, ölünün gömüldüğü yer anlamında kullanılmaktadır. Mezar kelimesinin Arapçadaki eş anlamlıları kabr (قبر) -çoğulu kubur (قبور)-, medfene (مدفو) -çoğulu medafin (مدافن)-, turbe (تربة) -çoğulu turab (ترب) dir. Mezarların bulunduğu mezarlık denilen mekânlara, Arapçada aynı zamanda makbera (مقبرة) -çoğulu mekabir (مقابر)- , çبانة)-çoğulu cebbanat (جبانات) denilmektedir”; ayrıca mezarlık için sadece Mısırlılar tarafından karafe (قبران) kelimesi de kullanılmaktadır. ${ }^{2}$

Piramit, eski yunanca pyramis kelimesinin Fransızcaya geçmiş şeklidir. Mısırlılar, piramit karşıı̆ı olarak harem (هرم) kelimesini kullanmaktadır; ancak bu kelimenin çoğul şekli olan ehram (أهرم) ya da ehramat (هرم)ات)'ın kullanımı daha yaygındır. Ehram ya da ehramat kelimesi ile daha ziyade Mısır'ın anıt mezarları kastedilmektedir. $^{3}$

Tarih boyu toplumların cesede yaklaşımları farklılık göstermektedir. Bu yaklaşımlar cesedi gizlemeyi istemek, pis kabul ederek ondan bir an önce kurtulmaya çalışmak, ölü dahi olsa insana ait olduğundan saygı ve hürmet duymak, dışarıda bırakıldığında çevreye vereceği zararı önlemeye çalışmak şeklinde görülmektedir. ${ }^{4}$ Bütün bu yaklaşımlar neticesi mezarlar ortaya çıkmış ve zaman içerisinde mezar kültürü gelişmiştir.

Mezarlarla ilgili elde edilen ilk bilgiler tarih öncesi zamanda yaşayan Sumer, Asur, Hitit ve Mısır uygarlıklarına aittir. Gerek tarih öncesi gerekse tarih sonrası yaşayan toplumların ölülerini defin işlemleri birbirlerinden farklılık göstermektedir. Çin, Hint ve Japon gibi bazı uzak doğu toplumlarında cesetler ya açıkta ya da fırınlarda yakılarak/kremasyon külleri saklanmakta veya kutsal kabul edilen Ganj nehri gibi yerlere atılmaktadır; zira bu bölge halklarının mensup olduğu Hinduizm ve Budizm'de cesetlerin yakılması önemlidir. Zerdüştlük'te ise ölüler murdar kabul edilmektedir. Bu sebeple onları gömmek toprağı kirletme, yakmak ise ateşe saygısızılık olarak değerlendirilmektedir. Bu sebeple Zerdüştler ölülerini, 'sessizlik kulesi' adını verdikleri yüksek mekânlarda yemesi için yırtıcı

1 bk. İbrahim Mustafa vd., el-Mu 'cemü'l-vešıț (İstanbul: Çağrı Yay., ts.), "zâre", "ḳabr", "defn", "turb", "cebene", 83,106,289,408, 717; bk. Cubran Mesud, er-Râ'id (Beyrut: Dâru'l-ilmu'l-melâyîn, 2003), "mezâr", "ḳabr", "medfene", "turbe", "cebbâne", 238, 304, 685, 802, 812.

2 Bu bilgi yaşadığım Mısır tecrübelerimdendir.

3 bk. Mustafa, “heram”, 993; Mesud, “heram”, 928; bk. Türkçe Etimoloji Sözlüğü, “Ehram” (Erişim 11 Mayıs 2020).

4 bk. Halid Muhammed Abdi'I-lah el-Heddar, Dirâsetu'l-ḳubûri'l-ferdiyye (Bingazi: Câmiatu Kâryûnis, 2006), 1/77; bk. Salih b. Mukbili'I-Useymi't-Temimî, Bed 'u'l-kubûri 'enva 'uha ve 'ahkâmuha (Riyad: Daru'l-Fadıla, 1425 / 2004), 102. Mesela hayvan ölüleri dışarıda kaldıklarında kısa bir süre sonra kokuşmakta ve çevreye zarar vermektedirler. Öte yandan insan ölüsü farklı sebeplerden dolayı defni geciktiğinde bozulmaması için morglarda bekletilmektedir. 
kuşlara terk etmektedir. Helenistik dönemde de masrafsız bir yöntem olmasından dolayı fakirler tarafından cesetleri yakmanın tercih edildiği bilinmektedir. Bu farklı işlemlerle birlikte en yaygın olan cesetlerin toprağa gömülmesi/inhumasyon dir. Gömme işlemi neticesi oluşan mezarlar tekli, ikili, toplu olup en yaygın şekli tekli olanlarıdır. Tekli mezarlar aynı zamanda Helenistik dönemin yaygın şekillerinden olup Mısırın yanısıra Şam, Filistin ve Ürdün'de de görülmektedir. ${ }^{5}$

Mezarlıklar genelde yerleşim alanları dışında -arkeolojik ismi extramuraloluşturulur. Bunun yanı sıra az da olsa yerleşim alanları içerisinde oluşturulan mezarlıklar/intramural da vardır.

Tarihi süreç içerisinde toplum yapılarına, ekonomik ve coğrafi koşullara göre değişen farklı mezarlar görülmektedir.

\subsection{Mezar Çeşitleri}

Mezar çeşitleri, basit toprak mezarlar, kaya mezarlar, sandık mezarlar, küp mezarlar ve oda mezarlar olarak sınıflandırılabilmektedir;

Basit Toprak Mezarlar: Toprakta kare, dikdörtgen bazen de düzensiz şekilde açılan çukurlara ölünün cenin ya da düz pozisyonda konulmasıdır. Anadolu'daki en yaygın mezar tipidir. Bu mezarların üstü toprakla ya da taşla kapatılmaktadır. ${ }^{6}$

Sandık Mezarlar: Bu mezarlar görüntü olarak sandığa benzediğinden bu şekilde isimlendirilmektedir. Bu tip mezarlarda önce taş ya da toprak zemin kazılır. Buranın etrafı taş, ağaç, kerpiç gibi şeylerle yapılarak kare ya da dikdörtgen bina haline getirilir. Bina haline getirilen bu yerin üstü taşlarla farklı şekillerde kapatılır. Örtü olarak kullanılan taş, bazen dikdörtgen şeklinde tek blok ${ }^{7}$ halinde bazen de mezarın büyüklüğüne göre birden fazla -iki ile beş arası- parçalardan oluşmaktadır. Bu tip mezarlar Helenistik dönemde görülen şekillerdendir. ${ }^{8}$

Hellenistik Dönemde bazen de kare şeklinde yapılan odanın ortadan çakıl bir plakayla bölünmesiyle bitişik iki mezar oluşturulur. Bunun farklı sebepleri vardır; Bunlardan biri Grek inancına göre cesedin pis kabul edilerek ondan bir an önce kurtulma isteğidir. Bu şekilde vakit kaybetmeden iki kişi yan yana gömülebilmektedir. Fakirler tarafından çok tercih edilen başka bir sebep de zirai alanları koruma, güç ve masraftan tasarruf sağlamadır. ${ }^{9}$

5 bk. Kürşat Demirci, "Kabir", Türkiye Diyanet Vakfı İlam Ansiklopedisi (İstanbul: TDV Yayınları, 2001), 24/34; bk. a. mlf. "Cenaze", Türkiye Diyanet Vakfı İlam Ansiklopedisi (Istanbul: TDV Yayınları, 1993), 7/353-354; bk. Heddar, Dirâsetu'l-kubûri'l-ferdiyye, 1/77, 209.

6 bk. Derya Yılmaz, "Erken Tunç Çağı'nda Güney Doğu Anadolu'da Oda Mezar Geleneği”, Anadolu 31 (2006), 67. bk. Heddar, Dirâsetu'l-kubûri'l-ferdiyye, 1/216; bk. Sevil Özterzi, Anadolu'da Neolitik ve Kalkolitik Dönemdeki Mezar Tiplerinin ve Ölü Gömme Geleneklerinin Sosyokültürel Açıdan Değerlendirilmesi (Ankara: Ankara Üniversitesi, Sosyal Bilimler Enstitüsü, Yüksek Lisans Tezi, 2011), 21.

7 Tek blok olması taşın kaldırılması, hareket ettirilmesi zor olduğundan kabir daha emniyetli olmaktadır. bk. Heddar, Dirâsetu'l-kubûri'l-ferdiyye, 1/137.

8 bk. Heddar, Dirâsetu'l-kubûri'l-ferdiyye, 1/137; bk. Sevil Özterzi, s. 23.

9 bk. Heddar, Dirâsetu'l-kubûri'l-ferdiyye, 1/161. 
Küp Mezarlar: Ölü bedenin ebatlarına uygun küpe konularak ağzının sıkıca kapatılmasıdır.

Oda/Kaya Mezarlar: Taş, kerpiç ya da kayalara oda tarzında yapılan yerlere ya da yerli büyük kaya kütlelerinin oyuk ve aralıklarına ölülerin gömülmesidir. Bunlar, daha ziyade aynı kabre birden fazla cesedin konulması ile oluşturulan toplu aile mezarlarıdır. Bu bazen önceki cesedin kemiklerinin bir köşeye toplanarak yeni cesedin yerleştirilmesi bazen de aralarının bir tabaka ile ayrılarak iki cesedin üst üste konulması tarzındadır. ${ }^{10}$

Oda mezarların çatısı ve kapısı bulunmaktadır. Bu mezarlar aynı zamanda anma ve kurban törenleri için kullanılır. Bu mezar tipi Romalılar zamanında çok yaygındır. Anadolu'da da bu tip mezarlar görülmektedir. ${ }^{11}$

Farklı mezar tiplerinin oluşmasında coğrafi şartlar, kültür ve inanç etkili olmaktadır. Mesela Taş çağı olarak bilinen dönemlerde, ölülerin hayatlarını devam ettireceğine inanıldığından, cesedin yanına bir miktar yiyecek ve bazı eşyalarda konulmuştur. Konulan eşyalar bardak, tabak, tas, ibrik gibi şeylerdir. Bunların yanı sıra kadınlarda dokuma ve dikiş aletleri, taç, ayna, bilezik, küpe, gerdanlık gibi süs eşyaları; erkeklerde ise farklı olarak silahlar, savaş aletleri cesetlerin yanında bulunmuştur. Öte yandan Grekler, mezarların üzerine ölünün yararına olması ve toprağın tekrar kullanılabilir hâle gelmesi için buğday gibi tahıl türleri ekmiştir. ${ }^{12}$

Dini açıdan defin konusuna baktığımızda, cesetlerin gömülmesi gerektiğini belirten dinlerin başında Yahudilik, Hristiyanlık ve İslam gelmektedir.

\subsection{Yahudilik'de Mezar}

Tanah'ta anlatılanlara göre Yahudiler ortaçağa kadar cesetlerini kaya kovuklarına koymuşlardır. İbrahim'in karısı Sara'yı Makbela Mağarasına gömdüğü, ${ }^{13}$ sonra İshak ve İsmail'in babaları İbrahim'i de aynı mağaraya gömdüğü ${ }^{14}$ daha sonra Yakub'un da kendi vasiyeti üzere bu mağaraya gömüldüğü nakledilmektedir. ${ }^{15}$ Yahudiler'de gömme tarzındaki mezar kültürü zamanla oluşmuştur. Buna göre Yahudiler inançları gereği ölen kişinin ağzını gözünü kapamakta, tırnak-kıl temizliğini yapmakta, yıkamakta, kefenlemekte sonra da tabutla birlikte ${ }^{16}$ gömmektedir. İlk olarak da Yusuf Peygamberin tabuta konulduğu bilinmektedir. ${ }^{17}$ Ondan sonra tabutla gömme âdet olmuştur.

10 bk. Heddar, Dirâsetu'l-ḳubûri'l-ferdiyye, 1/199.

11 bk. Yılmaz, "Erken Tunç Çağı'nda Güney Doğu Anadolu'da Oda Mezar Geleneği”, 67-68; Bk. Özterzi, Anadolu'da Neolitik ve Kalkolitik Dönemdeki Mezar Tiplerinin ve Ölü Gömme Geleneklerinin Sosyokültürel Açıdan Değerlendirilmesi, 21-23; bk. Heddar, Dirâsetu'l-kubûri'l-ferdiyye, 1/77, 137. Bu mezarların büyüklüğü ölen kişinin fiziki yapısına göre değişir. Mesela Orta büyüklükteki bir helenestik dönem mezarda en fazla üç blok taş kullanılır. Örtülen taşların genişliği 20, kalınlığı ise $15-45 \mathrm{~cm}$ arası değişmektedir. bk. Heddar, Dirâsetu'l-kubûri'l-ferdiyye, $1 / 143$.

12 bk. Heddar, Dirâsetu'l-kubûri'l-ferdiyye, 1/239-245; bk. Demirci, “Kabir", 24/34.

13 bk. Kitab-ı Mukaddes, (İstanbul: Kitab-ı Mukaddes Şirketi, 1993), Yaradılış 23.

14 bk. Yaradııış 25/8-10.

15 bk. Yaradılış 49/29-31, 50/12-14; bk. Demirci, "Cenaze", 7/354.

16 bk. Demirci, "Kabir", 24/34.

17 bk. Yaradılış 50/26. 


\subsection{Hristiyanlık'da Mezar}

Hristiyanlık bir yerde Yahudiliğin devamı kabul edildiğinden onlarla aynı mezar kültürüne sahiptirler. Hristiyanlarda da Yahudilerde olduğu gibi ölen kişi yıkanır, temizlenir, kefenlenir ve tabut ile gömülür. ${ }^{18}$ Yaygın olan cesedi gömmek olmakla birlikte çok az da olsa yakma işlemi de görülmektedir. Hristiyan mezarlıkları genelde aile mezarları şeklinde olup şehrin dışında oluşturulmuştur. ${ }^{19}$

\section{4. İslam'da Mezar}

Araştırma konumuzun odağında bulunan Kahire'nin mezar evlerinde yaşayan kişiler Müslüman olduklarından, onların bu tutumlarını daha iyi temellendirebilmek ve anlayabilmek için, "İslam'da defin ve mezar adetlerini biraz daha geniş olarak ele alacağız.

İslam'da ölü için yapılan hazırlıklara teçhiz, yıkanmasına gasil, kefenlenmesine tekfin, konulacağı yere taşınmasına teşyi, toprağa gömülmesine defin, defnedildiği yere de mezar ya da kabir denir. ${ }^{20}$

Kur’an'ın bazı ayetleri ölünün gömülmesinin gerekliliğiyle irtibatlandırılmıştır. Bunlar;

"Sizi oradan yarattık, yine ona döndüreceğiz ve sonra oradan bir defa daha çıkaracağız."21; "Biz yeryüzünü dirilere ve ölülere toplanma yeri yapmadık mı?"22; "Nihayet onun canını aldı ve kabre koydu, sonra dilediği bir vakitte onu yeniden diriltir."23

İlk ölü gömme olayından Kur'an'da bahsedilmektedir. "Onlara Adem'in iki oğlunun haberini gerçek olarak oku. Hani ikisi de birer kurban sunmuşlardı da birininki kabul edilmiş, diğerinden kabul edilmemişti. (Kurbanı kabul edilmeyen) 'Andolsun seni mutlaka öldüreceğim' dedi. Öteki 'Allah ancak kendisine karşı gelmekten sakınanlardan kabul eder, andolsun sen beni öldürmek için elini bana uzatsan da ben seni öldürmek için sana elimi uzatacak değilim; çünkü ben alemlerin Rabbi olan Allah'dan korkarım. Ben istiyorum ki sen benim günahımı da kendi günahını da yüklenip cehennemliklerden olasın. Işste bu zalimlerin cezasıdır. Derken nefsi onu kardeşini öldürmeye itti de onu öldürdü ve böylece ziyan edenlerden oldu. Nihayet Allah, ona kardeşinin ölmüş cesedini nasıl örtüp gizleyeceğini göstermek için

18 bk. Resullerin İşleri 9/37; bk. Markos, 15/42-46.

19 bk. Demirci, “Kabir", 24/34; bk. Şahin Kızılabdullah, "Pre and Post-Death Rituals in Christianity: A Phenomenological Analysis", Türkiye Ilahiyat Araştırmaları Dergisi 3/1 (June 2019), 125-130.

20 bk. Demirci, “Cenaze", 7/353.

21 Kur'an-ı Kerîm ve Açıklamalı Meali, çev. Ali Özek vd., (Ankara:Türkiye Diyanet Vakfı Yay., 1993), et-Ṭâhâ 20/55; bk. Kur'an Yolu, Hayreddin Karaman vd., (Ankara: Diyanet Iş̧leri Başkanlığı Yayınları, 2012), 3/632-637.

22 el-Murselât 77/25-26; bk. Ebu Cafer Muhammed b. Cerir et-Taberî, Taberî tefsîri, çev. Kerim Aytekin-Hasan Karakaya (İstanbul: Hisar Yayınevi, 1996), 8/534-535; bk. İmam Kurtubi, el-Câmi'u li'ậkâmi'l-Kur'an, çev. M. Beşir Eryarsoy (İstanbul: Buruc Yay., 1997-2006), 18/314-316.

23 el-'Abese 80/21-22; bk. Karaman vd., Kur'an Yolu, 5/553-557; bk. Kurtubi, el-Câmi'u li'aḥkâmi'l-Kur'an, 18/408411. 
yeri eşeleyen bir karga gönderdi 'Yazıklar olsun bana! Şu karga kadar olamadım mı ki, kardeşimin cesedini gömeyim' dedi. Artık pişmanlık duyanlardan oldu."24

Müfessirlere göre ayetlerde bahsedilen kişiler Adem'in Habil ve Kabil adlı iki oğludur. Kabil kıskançlık neticesi Habil'i öldürür. Kabil, öldürdüğü kardeşinin cesedini ne yapacağını düşünürken Allah, kardeş iki karga gönderir ve onlardan biri diğerini öldürür sonra da toprağı eşeleyerek onun üzerini örter. Başka bir rivayete göre de karga toprağı kazarak yiyeceğini gizler. Böylece, insanların toprağı kazarak ölüleri gömmeyi öğrendikleri ifade edilmektedir. ${ }^{25}$

Ölülerin gömülmesi gerektiği Hz. Muhammed tarafından da ifade edilmiştir. ${ }^{26}$ Bu bağlamda İslam uleması, cesetlerin gömülmesi konusunda görüş birliğine varmıştır. ${ }^{27}$ Gömme tarzında oluşturulan kabirlerin ne çok yüksek ne de çok alçak olmayıp, varlığı fark edilebilecek şekilde düzgün yapılması gerektiği belirtilmiştir. $^{28}$

Kur'an'ın ifadesi ile insan eşrefi mahlukat yani yaratıkların en şereflisidir. ${ }^{29} \mathrm{Bu}$ bağlamda onun dirisinin yanı sıra ölüsü de değerli kabul edilmektedir. Nitekim Hz. Muhammed bir sohbet esnasında cenazenin geçtiğini gördüğünde, hemen ayağa kalkmış ve ashabına bunun insan ölüsüne saygının bir gereği olduğunu belirterek onlara da cenaze gördüklerinde aynı şeyi yapmalarını tavsiye etmiştir. ${ }^{30}$ Hz. Muhammed ayrıca ölü dahi olsa kişiye sövülmemesi gerektiğini belirterek insana verdiği değeri belirtmiştir. ${ }^{31}$

Öte taraftan ölen kişiye ait cesedin yıkanması, koku sürülmesi, cenaze namazının kılınması sonra da defnedilmesi ona verilen değerin ifade şeklidir. Aynı zamanda cesedin gömülmesi de onu herhangi bir zarar ve saldırıdan korumak amaçlıdır. ${ }^{32}$

İslamî usullere göre ölen kişiler birkaç şekilde defnedilebilmektedir. Bunların en yaygın olanı 'şakk' denen gömme ya da 'lahd' denilen mezar açma şeklinde kişinin tek olarak gömülmesidir. Şakk, açılan mezarın alt kısmına cesedin konulması şeklindedir. Lahd ise mezar açıldıktan sonra toprağın yan tarafında tekrar bir oyuk yapılır ve ceset buraya konularak üzeri taşlarla örtülür, onun üzerine de toprak atılır. Hz. Muhammed'in lahd tipi mezara gömüldüğü rivayet

24 el-Mâ'ide 5/27-31

25 bk. Taberî, Taberî tefsîri, 3/268-269; bk. Kurtubi, el-Câmi'u li'ahkâmi'l-Kur'an, 6/17-1-175.

26 bk. Ebu Dâvud Süleyman b. el-Eş’as es-Sicistani, Süneni Ebî Dâvud, nşr. Muhammed Nasiri'd-din Albani (Riyad: Mektebetu'I Mearif, 1427/2007), “Kitâbu'l-Cenâ'iz”, 15/71; bk. Ebi Abdi'llah Muhammed b. Yezidi'l-Kazvînî (İbn Mace), Süneni ibn Mâce, nşr. Muhammed Nasiri'd-din Albani (Riyad: Mektebetu'l Mearif, 1429/2008), “Kitâbu'lCenâ'iz", 6/41.

27 bk. Temimî, Bed 'u'l-kubûri 'enva 'uha ve 'ahḳ̂amuha,102.

28 bk. Ebu Davud, "Kitâbu'l-Cenâ'iz", 15/72.

29 bk. et-Tîn 95/4.

30 bk. Ebu Hüseyin Müslim b. el-Haccac el-Kuşeyrî en-Neysâbûrî, Șaḥiḥi Müslim, nşr. Muhammed b. Nasıri'd-din Albani (Kahire: Daru't-Takva, 1434/2012), "Kitâbu'l-Cenâ'iz", 11/ 24.

31 bk. Muhammed b. İsmail el-Buharî, Șahihụu'l-Buhârî, nşr. Ahmed Muhammed Şakir (Kahire: Muessestu Zâd, 1433/2012), "Kitâbu'l-Cenâ'iz", 23/97.

32 bk. Taberî, Taberî tefsîri, 8/534-535. 
edilir. İmam Malik'ten nakledilen bu rivayete göre, peygamber vefat ettiğinde Medine'de biri şak diğeri de lahd tarzında mezar açan iki kişi vardı, halk bunlardan hangisi önce gelirse peygamberin ona göre gömülmesine karar verir. Bu karardan sonra lahd tarzında mezar açan kişi önce gelir ve mezarı açar. Bunun üzerine $\mathrm{Hz}$. Muhammed lahd tarzında açılan bu mezara gömülür. ${ }^{33}$

Bu iki usul normal şartlarda geçerli olmakla birlikte, zamanla toprağın azalması, yeterli yer bulunmaması, arazinin sertliğinden dolayı mezar açmaya elverişli olmaması, arazi fiyatlarının artması gibi zaruri durumlarda bir mezara aynı cinsiyete sahip birden fazla kişi konulabileceği ve ölülerin kemiklerinin karışmaması -farklı zamanlarda olduğunda- için de aralarına bir engel koyulmasının gerekli olduğu belirtilmektedir. Bu engelin birincinin üzerinin tümüyle toprakla örtülmesi ve ikincinin de onun üzerine konulması şeklinde olabileceği ifade edilmektedir. Tabii afet ya da savaş gibi durumlarda -aynı zamanda gömülmesi gereken çok kişi olduğundan- aralarında toprak set oluşturarak bir mezara birden fazla kişi konulabilmektedir; zira Hz. Muhammed, Uhud savaşı sonunda şehitlerin aynı mezara ikişer üçer konulmasına izin vermiştir. ${ }^{34}$ Yine ihtiyaca binaen daha sonra çürüyen ceset kemikleri bir tarafa toplanıp mezara yeni bir ölü konulabilmektedir. Bir mezara birden fazla kişinin konulabileceği konusunda dört mezhep arasında görüş birliği bulunmaktadır. ${ }^{35}$

Mezarların pek çoğunun üst kısımları vardır ve buralar dikkat çekmektedir. Bu kısımda üzerinde mezardaki şahsın kimlik bilgilerinin ya da sadece isminin yazılı olduğu mezar taşı -ekseriyetle mermerden olan tercih edilir- bulunmaktadır. Illk mezar taşının ne zaman dikildiği kesin olmamakla birlikte Yahudi kutsal kitaplarında Yakub'un ölen eşi Rahel'in kabrine diktiği mezar taşından bahsedilmektedir. ${ }^{36}$ İslam'dan sonra da Hz. Muhammed'in Osman b. Mazun'a ait mezarın baş tarafına mezar taşını bizzat kendisinin koyduğu nakledilmektedir. ${ }^{37}$ Buradan da kabrin belirlenmesinin gerekli olduğu anlaşılabilmektedir.

Bunların yanı sıra kabir üzerine mescid, oda gibi bina ya da kubbe yapmayı $\mathrm{Hz}$. Muhammed nehiy etmiştir. ${ }^{38}$ Dört mezhepte bu nehiy konusunda ittifak etmiştir. ${ }^{39}$

33 bk. Malik b. Enes, el-Muvațțâ, haz. Yahya b. Yahya el-Lisi'l-Endulisî, nşr. Muhammed b. Nasıri'd-din Albani (Kahire: Dâru ibni'l-Cevzi, 2010), "Kitâbu'I-Cenâ'iz", 16/10.

34 bk. Muhammed b. İsa et-Tirmizi, Süneni Tirmižî, nşr. Muhammed b. Nasıri'd-din Albani (Riyad : Mektebetu'lMearif li'n-neşr ve't-tevzi', 1429/2008), “Kitâbu'l-Cihâd", 21/33; bk. Ebu Davud, “Kitâbu'I-Cenâ'iz", 15/71.

35 bk. Abdu'r-rahman b. Muhammed 'Avad el-Cuzeyrî, el-Fikhu 'al'a'l-Mezahibi'l-'Erbi'a, (Mansura/Mısır: Daru'lĠadi'l-Cedid, 1436/2015), 303; bk. Mehmet Şener, “Kabir", Türkiye Diyanet Vakfı İlam Ansiklopedisi (İstanbul:TDV Yay., 2001), 24/35; bk. Mustafa Uzunpostalcı, "Defin”, Türkiye Diyanet Vakfı İslam Ansiklopedisi (İstanbul: TDV Yay., 1994), 9/86.

36 bk. Yaradılış 35/19-20. Türk kültüründe de mezar taşları çok önemli yer tutmaktadır. Eski türklerde mezar üzerine bina yapılır, duvarlarına da ölüyle ilgili bilgiler yazılır ya da resmedilirdi. Bu kültür türklerin İslam’ kabul etmesinden sonra mezar taşlarına dönüştürülmüştür. Bazı mezar taşları kitabe şeklinde idi. Bunun en güzel örneği Orhun yazıtlarıdır. bk. Nebi Bozkurt, "Mezarlık”, Türkiye Diyanet Vakfı İlam Ansiklopedisi, (Ankara TDV Yay., 2004), 297/519.

37 bk. Ebu Davud, “Kitâbu'l-Cenâ'iz", 15/63.

38 bk. İbn Mace, "Kitâbu'l-Cenâ'iz", 6/43.

39 bk. Müslim, "Kitâbu'l-Cenâ'iz", 11/ 33; bk. Cuzeyrî, el-Fıkhu 'al'a'I-Meżahibi'l-'Erbi'a, 302. 
Öte yandan Hz. Muhammed mezar üzerinde oturmak, yürümek, tuvalet ihtiyacı gidermek, namaz kılmak ya da namazda mezara doğru yönelmenin caiz olmadığını belirtmiş̧tir. ${ }^{40}$

Mezarlıklar genelde yerleşim alanları dışında oluşturulmuş ancak bu alanlarının zamanla genişlemesi ile pek çok mezarlık iskan mekânları içerisinde kalmıştır. Ayrıca önemli şahsiyetlerin defnedildikleri yerlerin etrafında da küçük mezarlıklar oluşturulmuştur. Bu küçük mezarlıklara daha ziyade hazire denilmektedir. ${ }^{41}$

İslami açıdan mezar hakkında verdiğimiz bilgileri kısaca özetleyebiliriz;

1. Mezarlık olarak genelde yerleşim alanları dışında yerler tercih edilmektedir.

2. Kabrin uzunluğu, geniş̧liği standart olmayıp bunlar kişinin fiziki yapısına göre ayarlanmaktadır.

3. Mezarlara şakk ya da lahd olarak iki şekilde defin yapılabilir ancak lahd daha çok tercih edilmektedir.

4. Kabirlerin yerden bir ya da iki karış yüksek olabileceği ifade edilmektedir.

5. Kabrin kaybolmaması için üzerinde kişinin kimlik bilgilerinin yazılı olduğu taş, tahta gibi belirleyici şeylerin dikilmesinin uygun olduğu belirtilmektedir.

6. Mezarın üstü toprak ile düzleştirileceği gibi tümsek de oluşturulabilmektedir. Tercih edilen hafif tümsek olmasıdır.

7. Mezarların üzerine basmak, çiğnemek ve yürümenin caiz olmadığı ifade edilmektedir.

8. Mezarların üzerinde oturmak ya da tuvalet ihtiyacını gidermek uygun görülmemektedir.

9. Mezarların üzerine oda, mescit gibi bina yapmak ve kubbe dikmek caiz görülmemektedir.

10. Mezarların üzerini kazmak uygun olmayan işlemlerden kabul edilmektedir.

11. Mezar üzerinde namaz kılmak ya da namazı mezara yönelerek eda etmek uygun görülmemektedir.

12. İslam'a göre insanın dirisi gibi ölüsüne de saygı göstermek gereklidir.

\section{Mısır'da Mezarlar}

Mısır'daki mezar kültürünü iyice anlamamız için Mısır tarihindeki ölü gömmeyle ilgili icraatlara bakmamız gereklidir.

Mısır, hakkında en eski tarihi bilgilere sahip olunan bölgelerden biri kabul edilir. Mısır tarihini firavunlar öncesi ve firavunlar/hanedanlar dönemi olmaküzere

40 bk. Müslim, "Kitâbu'l-Cenâ'iz", 11/33, Hadis No: 96, 97, 98 (971, 972, 973); bk. Ebu Davud, "Kitâbu'I-Cenâ'iz", 15/77; bk. İbn Mace, “Kitâbu'l-Cenâ'iz", 6/45.

41 İstanbul'daki Eyüp Mezarlığı, Kahire'deki İmam Şafii Mezarlığı gibi. bk. Bozkurt, "Mezarlık”, 29/520. 
ikiye ayırmak mümkündür. Firavunlar öncesi dönemin başlangıcı konusunda farklı görüşler olsa da MÖ 3100 ya da 3200 yılları kabul edilendir.42

Eski Mısırlılar'da Firavunlar dönemi otuz bir hanedanıyla hüküm sürülen uzun bir zaman dilimini kapsamaktadır. Bu dönem kronolojik olarak şöyle sıralanmaktadır:

Eski Krallık Dönemi / Antik Mısır -birden yedinci hanedana kadar- (MÖ 3.100MÖ 2.180)

1. İstikrarsız Dönem -yediden on birinci hanedana kadar- (MÖ 2181-MÖ 1991) 1.690)

Orta Krallık Dönemi -on birden on beşinci hanedana kadar- (MÖ 2.134-MÖ

\section{Ara Dönem -on beşten on sekizinci hanedana kadar- (MÖ 1674-1549)}

Yeni Krallık Dönemi -onse kizden yirmi birinci hanedana kadar- (MÖ 1.549-MÖ 1069) Son Ara Dönem -yirmi birden yirmi yedinci hanedana kadar- (MÖ 1069-MÖ 653) Pers ve Geç Hanedanlık Dönemi -yirmi sekizden otuz birinci hanedanlığın sonuna kadar- (MÖ 672-MS 332) ${ }^{43}$.

$\mathrm{Bu}$ dönemlere ait tarihi bilgiler mabed duvarları, taşlar üzerine çizilen/ nakşedilen resimler, yazılar ya da papürüslere yazılan idari, edebi konularla ilgili bilgilerden oluşmaktadır. Resimlerle daha ziyade firavunların yaptıkları savaşlar, firavun ya da ileri gelen kişilerin hayatlarıyla ilgili bilgiler ve dini törenler anlatılmaktadır. ${ }^{44}$

Mısırda ölen kişiler birkaç şekilde defnedilirdi. Birden fazla kişi bir mezara konulur ya da ölü, duvar içerisinde bir yere yerleştirilerek üzeri de oymalı Grek tarzında süslü bir şekilde, isminin yazıldığı taşlarla kapatılırdı. Ölünün cesedinden ayrıştırılarak kemikleri ayrı bir yere konulurdu. ${ }^{45}$ Diğer bir gömme şekli de cesedin, ayakları karına çekilerek elleri ile sarılır; başı, birlikte yaşadığı ailesinin evine yönelik ${ }^{46}$ vaziyette hasır ya da deriye dolanarak oval şekilde açılan çukura yerleştirilirdi. Bu çukurlar daha sonra kare şeklinde odaya dönüştürülerek, üzerlerine kumdan ya da çakıl taşından oluşan tümsekler yapılırdı. Zamanla mezarlarlardaki tümsekli oda sayısı çoğaltıldı ve üzerlerinde toprak üstü set oluşturuldu, sonrasında bu toprak setlerden basamaklı piramit oluşturuldu. Basamaklı piramitler de zamanla tam piramit şekline dönüştürüldü. ${ }^{47}$

\footnotetext{
bk. Selîm Hasan, Mevsû'atu Mıșri'I-ḳadîme, ed. Semîr Serhân (Kahire: Mektebetu'I-'Usra, 2001), 1/154.

Bu tarihler kesin olmayıp kaynaklar arasında farklılıklar bulunmaktadır.

bk. Hasan, Mevsû'atu Mıșri'-kadîme, 1/158.

bk. Hasan, Mevsû'atu Mıșri'l-ḳadîme, 1/95.

Bu şekilde daha önce sahip olduklarını, yaşadığı yeri ve ailesini sürekli olarak görebileceğine inanılmaktadır. Daha sonra tabut üzerine iki göz resminin çizilmesi bu inancı desteklemektedir. bk. Hasan, Mevsû'atu Mıșri'lkadîme, $1 / 94$.

47 bk. Mahmûd Mursî Muhammed Cârihî, "Merâhịilu tațavvuri şekli'l-maḳberati'l-melikiyyeti fî Mıșri'l-ḳadîme”, Mecelleti'l-'imârati ve'l-funûn 10 (2018), 544; bk. Heddar, Dirâsetu'l-kubûri'l-ferdiyye, 1/204-205, 212.
} 
Eski Mısır'da firavunlar ve saygın kişiler için anıt mezarlar diğer adıyla piramitler inşa edilmiştir. Piramitler yapılış şekilleri, mimarileri ve ebatlarıyla birbirlerinden farklı görünüme sahip olmuştur. Piramitlerin bir kısmı yerin altında bir kısmı ise yerin üstünde taştan ya da kerpiçten binalar şeklinde yapılmıştır. Piramitler içerisine cesetler kıymetli eşyaları ile birlikte mumyalanarak konulmuştur. ${ }^{48}$

Mısır'ın birinci ve ikinci hanedanlarına mahsus belirli mezarlar yoktur. Mısır'ın kuzey kısmında özellikle Sakkara -eski adı menf/منف -bölgesinde toprak üzerinde hanedan mensuplarına mahsus kerpiç ve büyük taşlardan yapılmış mezarlar mevcuttur. Bu bölgede yine üçüncü hanedana mahsus mastaba tarzı mezarlar vardır. Mastaba ${ }^{49}$ tarzının ilk ve en eskisi bu hanedandan firavun Zoser $(ز)^{\prime}$ 'e aittir. Bu mezarlar içten ve dıştan kemerlerle görkemli duvarlara sahiptir; duvarların üzerinde dönemin sanatçıları tarafından yapılmış resimler ve yazılar bulunmaktadır. Bu resimler, bakan kişiye başka bir alemde devam ettirilecek olan ebedi hayatın varlığını hissettirmektedir. Zoser'in piramiti Mısır'da varlığını muhafaza eden en eski taş yapı sayılmaktadır. ${ }^{50}$

Dördüncü hanedanlığa piramitler dönemi denilebilmektedir. Mısır'ın ilk piramiti ve meşhur Giza piramitleri bu dönemin eseridir. İlk piramit bu dönemin kurucusu sayılan firavun Sneferu'ya (سنفرو) aittir. Sneferu'ya ait olduğu sanılan biri Feyyum girişinde Meydum (ميدوم) bölgesinde, diğeri ise Sakkara'nın kuzeyinde Dahshur (دهشور) bölgesinde iki piramit bulunmaktadır. Meydum anıt mezarı 20.880 metre karelik alanı ve 99 m yüksekliğiyle Antik Mısır mimarisinin ilk gerçek piramiti olarak kabul edilmekte ve kırmızı taşlarla yapıldığından dolayı kırmızı piramit olarak isimlendirilmektedir. Bu piramitin doğu tarafında defin işlemlerinin yapıldığı cenaze mabedi bulunmaktadır. ${ }^{51}$

Şeklinden dolayı "Bükülmüş Piramit" denilen Dahshur anıt mezarının bizzat firavun Sneferu'e tarafından yapıldığı belirtilmektedir. Bu piramit $101 \mathrm{~m}$ yüksekliğinde olup yüksek geniş bir kaide üzerine kurulmuştur. Sneferu'un bu iki mezardan hangisine defnedildiği bilinmemektedir. ${ }^{52}$

Sneferu'dan sonra yerine oğlu Kufu (خوفو) geçmiştir. Kufu'nun kaç yıl hüküm sürdüğü kesin olarak bilinmemekle beraber yirmi yıldan fazla olduğu belirtilmiştir. Hükmettiği bu yıllar içerisinde anıt mezarını kendisi yaptırmıştır. Bu mezar Giza'nın batı tarafında Harem bölgesinde yüksek bir tepe üzerine inşa

48 bk. Abdu'l-azîz es-Seyyidi'ş eş-Şinnâvi, el-Ma'bed ve'l-cebbânetu fi Mıșri'l-ḳadîme (Tanta/Mısır: Mațâbi' 'Abbâş, 2005), 169.

49 Mastaba, yer altına gömülen ölünün hatırlanması için üstü düz tepecik şeklinde yapılan anıt mezardır. Bunlar eski mezarlarla piramitler arasında bir halkadır. bk. Vikipedi, "Mastaba" (Erişim 13 Haziran 2020).

50 bk. Cârihî, "Merâhịilu tațavvuri şekli'I-maḳberati'l-melikiyyeti fî Mıșri'l-ḳadîme", 534; bk. Hasan, Mevsû'atu Mıșri'lkadîme, 1/269, 280, 287.

51 bk. Cârihî, "Merâhilu tațavvuri şekli'I-maḳberati'l-melikiyyeti fî Mıșri'l-ḳadîme”, 537; bk. Hasan, Mevsû'atu Mıșri'lkadìme, $1 / 284$.

52 bk. Cârihî, "Merâhịilu tațavvuri şekli'I-maḳberati'l-melikiyyeti fî Mıșri'l-ḳadîme", 537; bk. Hasan, Mevsû'atu Mıșri'lkadîme, $1 / 284$. 
edilen meşhur üç piramitin en büyüğüdür. 13 feddanlık ${ }^{53}$ geniş bir alan üzerine kurulan bu büyük piramitin yüksekliği $146.7 \mathrm{~m}$ dir. Piramitin dışı beyaz kireç taşı ile kaplıdır. Kral odasının yerden yüksekliği 42.28m, uzunluğu 10.5m., genişliği $5.25 \mathrm{~m}$ ve odanın kendi yüksekliği $5.82 \mathrm{~m}$ dir. Bu odanın duvarları tamamen parlak kırmızı renkli giranit kaplı olup tavanında Kufu'nun hakimiyetinin onyedi yılını anlatan yazıların olduğu bazı kitabeler ve işlenmiş nakışlar bulunmaktadır. Firavunun odasının dışında genişliği $25 \mathrm{~m}$ ye varan başka odaları da vardır. Bu piramitin yapımında 2.300.000.000 adet taş kullanılmış olup toplamda 6.000.000 ton ağırlığındadır. Kufu'nun nakşedilen resmi taşlardan birinin üzerindedir. Piramitin etrafı insanların yaklaşmasını engellemek amaçlı kalın duvarlar/surla çevrilidir. Bu görkemli piramitin yapımının yirmi yıl devam ettiği ve bu esnada da yüz bin işçi çalıştırıldığı belirtilmektedir. Bu piramitin üstün deha ürünü olduğu kabul edilmektedir. ${ }^{54}$ Kufu, bu piramiti kendisinin ebedi kalacağı bir yer olarak inşa ettirmiş olsa da defin odasında kabrinin boş bulunmasından içerisinde fazla kalamadığı anlaşılmaktadır. ${ }^{55}$

Kufu'dan sonra yerine geçen oğlu Hafra (خفرع)'nın anıt mezarı 215.2 metre karelik alanı ve $143.5 \mathrm{~m}$ lik yüksekliği ile Giza'daki üç büyük piramitten biridir. Kufu kadar büyük ve gösteriş̧i olmayan bu piramitin de birden fazla odası bulunmaktadır. Hemen yanında doğu tarafında defin işlemlerinin yapıldığı cenaze mabedi yer almaktadır. Buranın zemini mermer, duvarları kırmızı granit kaplı alçı taşındandır. Bu piramit, cenaze mabedi, vadi mabedi ve yukarıya çıkan yol olmak üzere dört kısımdan oluşmaktadır. ${ }^{56}$

Giza Bölgesinde yer alan üçüncü büyük piramit, Hafra'dan sonra başa geçen Menkaura (منكاورع)'a aittir. Yirmi yıl başta kaldığı tahmin edilen Menkaura, sağlığında anıt mezarını tamamlayamamıştır. Bu piramit daha sonra yerine geçen oğlu Shepseskaf (شبسكاف) tarafından yapımı bitirilmiştir. Menkaura Piramiti'nin dışı kırmızı taşla kaplıdır. Menkaura'nın cenaze mabedi beş odalı olup duvarları granit kaplı alçı taşındandır. Bu mabedden büyük bir koridorla dikdörtgen tarzında kerpiçten bir salona geçilir. Bu salonun ortasında suyu arındırmak için kullanılan alçı taşından bir havuz bulunmaktadır. Cenaze mabedi ile mezar arasında kurban kanının gitmesi için sunak, etlerin yenmesi için de sofra, kap, kacak vardır. Bunların yanı sıra mabedde 4. Hanedanla ilgili resimler ve Mankaura ile karısının granitten heykelleri mevcuttur. Bu iki heykel, zamanının en güzeli kabul edilir. ${ }^{57}$

53 Bir feddan $=4200$ metre karedir.

54 bk. Cârihî, “Merâhilu tațavvuri şekli'I-maḳberati'I-melikiyyeti fî Mıșri'l-ḳadîme”, 537-538; b9k. Hasan, Mevsû'atu Mıșri'l-kadîme, 1/290-291-294. Kufu piramitinin alt kısmında yer alan ana girişi Memun girişi olarak isimlendirilir; zira Halife Memun, dokuzuncu yüzyılda Mısır'ı ziyareti sırasında piramitin hazinelerini aramak için bu girişi açtırmıştır. bk. Cârihî, “Merâhhilu tațavvuri şekli'l-maḳberati'l-melikiyyeti fî Mıșri'l-ḳadîme”, 538.

55 bk. Hasan, Mevsû'atu Mıșri'l-kadîme, 1/294.

56 bk. Cârihî, "Merâhilu tațavvuri şekli'l-maḳberati'I-melikiyyeti fî Mıșri'l-ḳadîme", 538; bk. Şinnâvi, el-Ma'bed ve'lcebbânetu fi Mıșri'l-kadîme 61. Giza Piramitleri girişinde yer alan vücüdu aslan, başı insan olan Ebu'l Hul heykelinin Hafra'yı temsil ettiği kanaati vardır. bk. Hasan, Mevsû'atu Mıșri'l-kadîme, 1/300.

57 bk. Cârihî, "Merâḥilu tațavvuri şekli'I-maḳberati'l-melikiyyeti fî Mıșri'l-ḳadîme", 538; bk. Şinnâvi, el-Ma'bed ve'lcebbânetu fi Mıșri'l-ḳadîme, 61; bk. Hasan, Mevsû'atu Mıșri'l-ḳadîme, 1/312. 
Mankaura'dan sonra yönetime gelen Shepseskaf, kendi anıt mezarını basamaklı piramit şeklinde değil de mastaba tarzında yaptırmıştır. Böylece Shepseskaf, 4. Hanedan kralları arasında anıt mezarını basamaklı piramit tarzında yaptırmayan tek kral olarak kayda geçmiştir. Shepseskaf' mezarını büyük dedeleri gibi Sakkara bölgesinde inşa ettirmiştir. Bu anıt mezarın içerisinde ebadları 72 çarpı 100m, yüksekliği 18m olan büyük bir tabut yer almıştır. İçerisinde birkaç odanın olduğu bu anıt mezar, yerli kırmızı kum taşından yapılmıştır. Renginden dolayı bu anıt mezar aynı zamanda kırmızı piramit diye adlandırılmıştır; ancak bu piramitin çok az bir kısmı günümüze kadar ulaşabilmiştir. ${ }^{58}$

Dördüncü hanedandan sonra gelen beşinci hanedanın anıt mezarları, ekonomik durumun zayıflamasıyla öncekiler gibi büyük ve gösterişli bir görünüme sahip değildir. Bunlardan bazıları yüksekliği dokuz metreyi geçmeyen anıt mezarlar şeklindedir. Bunlar daha ziyade Usekaf (أوساحور) ve (أوسر كاف) Shura anıt mezarlarında olduğu gibi konik tepe görünümündedir. ${ }^{59}$

Beşinci hanedana ait anıt mezarların girişi tabutun indirilmesini sağlayan bir dehlize açılır. Defin işleminden sonra bu odaya giden yol barikatlarla kapatılır. Aynı şekilde definden sonra giriş büyük granit bloklarla set oluşturulur. Girişin tavanı genelde kireç taşından yapılan kitleler, üç tabaka halinde hörgüç /kambur şekilde yapılır. Bu geliştirilen yeni bir tarzdır. ${ }^{60}$

Altıncı hanedanın ilk kralı Unas (سنوانو)'dır.61 Unas'ın otuz yıl başta kaldığı ve anıt mezarını Haram bölgesinin kuzey batısında kendisinin yaptırdığı belirtilir. Bu mezarın duvarları 6 ve $57 \mathrm{~m}$, yüksekliği ise $40 \mathrm{~m}$ dir. Uras'ın anıt mezarı, büyüklüğü itibarıyla piramitlerin en küçüğü kabul edilmekle birlikte mimari açıdan son derece önemlidir. Bu piramitin defin odasının alt kısmı sade, üst kısmı ise yıldızlı nakışlarla süslü, duvarlarında ise sihirle ilgili sözleri ihtiva eden yazılar bulunmaktadır. Unas'ın mezarı ile Antik Mısır piramitleri gelişiminin sona erdiği kabul edilir. ${ }^{62}$

Antik Mısır'dan Orta Krallık'a kadar -MÖ 2181-1991-7, 8, 9 ve 10. HanedanlarMısır'ın istikrarsız yılları olup bu döneme ait anıt mezar ya da kalıcı bir eser yapılmamıştır. Bu dönemden sonra Orta Krallık'ın on birinci hanedanından 2. Mentuhotep (منتوحتب) Luksor'un Diri'l Bahr denilen bölgesinde anıt mezarını inşa ettirmiştir. Uzunluğu 1000 m, genişliği $46 \mathrm{~m}$, yüksekliği $3.15 \mathrm{~m}$ olan bu anıt mezar farklı bir tarzda edilmiştir. Bu piramit sanatsal açıdan zamanının en güzeli olarak

58 bk. Cârihî, "Merâḥilu tațavvuri şekli'I-maḳberati'l-melikiyyeti fî Mıșri'l-ḳadîme”, 539; bk. Hasan, Mevsû'atu Mıșri'lkadìme, $1 / 313$.

59 bk. Cârihî, "Merâḥilu tațavvuri şekli'l-maḳberati'l-melikiyyeti fî Mıșri'l-ḳadîme”, 539; bk. Hasan, Mevsû'atu Mıșri'lkadîme, $3 / 33$.

60 bk. Cârihî, "Merâḥilu tațavvuri şekli'l-maḳberati'l-melikiyyeti fî Mıșri'l-ḳadîme”, 539.

61 Bazılarına göre beşinci hanedanın son kralıdır. bk. Cârihî, "Merâḥilu tațavvuri şekli'l-maḳberati'l-melikiyyeti fî Mıșri'l-ḳadîme", 539.

62 bk. Cârihî, "Merâhịilu tațavvuri şekli'l-maḳberati'l-melikiyyeti fî Mıșri'l-ḳadîme", 539. 
kabul edilmekle birlikte günümüze sadece harabeleri kalmıştır. Bu piramitin mimarisinde Antik Mısır'dan bu yana var olan tüm anıt mezarların usluplarının kullanıldığı belirtilmiştir. Piramitin içerisine ölen kişinin daha sonra sürdüreceği hayatta ona hizmet edeceğine inanılan uşaptiler denen küçük cenaze heykelleri konulmuştur. Çok önem verilen uşaptiler menfezlere yerleştirilmiştir. ${ }^{63}$

Yer üzerindeki piramitler, tepe şeklinde görünüme sahip olup adeta sonsuzluk görüntüsü vermektedir. Pek çok odası olan bu piramitler görüntüsü ile ilah olarak kabul edilen kralın gücünün göstergesidir. Piramitler içerisindeki cesedin bulunduğu odaya merdivenle çıkılmakta ya da inilmektedir. Merdiven ruhun semaya yükselmesi, güneş ilahı Ra'ya yükselişin bir sembolü olarak düşünüldüğü belirtilmektedir. ${ }^{64}$

Piramitlerin yanlarında kahinlerin ve ölen kralın hizmetini yapanların oturduğu binalar ve genelde defin işlemlerinin yapıldığı cenaze mabedi vardı. Burada ölen kişi için dini tören yapılırdı. Törende dualar edilir, hesap günü ilahın lütfuna mazhar olabilmek için kurban / adak kesilir, sofra kurulur adak yemeği yenilir, ölen kişinin cesedinin mumyalama işi yapılırdı. ${ }^{65}$

Diğer yandan Mısır'ın Saidi denilen güney doğu bölgesinde antik zamanlara ait yer altında tek bir oda şeklinde kabirler bulunmaktadır. Bu odalar küçük taşlarla donatılmış, duvarları alçı ile kaplıdır. Alçıların üzerine Antik Mısır sanatçıları tarafından kişinin cenaze töreni gibi resimler mevcuttur. Bu resimler şimdiye dek orijinal halini muhafaza etmekte olup oldukça büyüleyicidir. ${ }^{66}$

Orta Krallıkta daha son zamanlarında anıt mezarlar iyice küçülmüştür. Bu dönemin en meşhur anıt mezarları onikinci hanedanlık tarafından Lişt'te ${ }^{67}$ inşa edilmiştir. Bunlar arasında 1. Amenemhat (أمنمحات), oğlu 1. Senusrat (سنوسرت) ' In kabirleri yer almıştır. Bunların mezarlarının yanında aynı zamanda devlet büyüklerinin de mezarları yapılmıştır. 2. Senusratın mezarı ise Feyyum yakınında Lahun (لاهون)'da bina edilmiştir. Bu devrin krallarından 3. Senusrat kendisi için iki anıt mezar yaptırmıştır. Kral 3. Amenemnat, Havvara (هوارة)'da koridorları ve pek çok odası olan bir anıt mezar yaptırmıştır. Defin odasına kuvarz taşından yapılmış büyük bir tabut konulmuş, kapısı da hırsızların girmesini engellemek için büyük bir taşla kapatılmıştır. Buna rağmen hırsızlar buraya tavandan girmişler, değerli şeyleri çalmış sonra da mezarı ateşe vermişlerdir.68

63 bk. Cârihî, "Merâḥilu tațavvuri şekli'l-maḳberati'l-melikiyyeti fî Mıșri'l-ḳadîme", 540-541; bk. Hasan, Mevsû'atu Mıșri'l-ḳadîme, 1/406-407.

64 bk. Cârihî, "Merâhịilu tațavvuri şekli'l-maḳberati'l-melikiyyeti fî Mıșri'l-ḳadîme”, 535.

65 bk. Şinnâvi, el-Ma'bed ve'l-cebbânetu fi Mıșri'l-kadîme, 61.

66 bk. Cârihî, "Merâḥilu tațavvuri şekli'l-maḳberati'l-melikiyyeti fî Mıșri'l-ḳadîme”, 534; Bk. Hasan, Mevsû'atu Mıșri'lkadîme, $1 / 267$.

67 Lişt: Burası Kahirenin güneyinde yer alan bir köydür.

68 bk. Cârihî,, "Merâhhilu tațavvuri şekli'l-maḳberati'I-melikiyyeti fî Mıșri'I-ḳadîme”, 542. 
Bu dönemde bazı zengin ve seçkin kişiler kendileri özel kabirler yaptırmakla birlikte, kralın ailesi ve yakınları da güvenlik açısından kayalara oyulan mezarlara gömülmüştür. ${ }^{69}$

Orta Krallıktan sonraki Yeni Krallık 18, 19 ve 20. Hanedanlar dönemi olmuştur. $\mathrm{Bu}$ dönemde Mısır gelişim açısından en ileri seviyeye ulaşmıştır. Daha önceki zamanlarda geometrik şekillerde yapılan piramitler bu dönemde bazı siyasi, ekonomik, sosyal sebeplerden dolayı farklılaşmıştır. Bu farklılık mezarlara yapılan nakışları dahi etkilemiştir. ${ }^{70}$

Gerek Antik Mısır'da gerekse Orta Krallık'ta anıt mezarlar içerisinden cesetlerin çalınması önlenememiş bu sebeple Yeni Krallık'ta cesetleri saklamaya büyük önem verilmiştir. 18. Hanedan döneminde Batı Vadi Teb Bölgesi'nde tepe arkasında gizli kayalıklar içerisinde saklı oyuklara mezar yapılarak cesetler buralara konulmuş ve burası "Krallar vadisi"71 olarak isimlendirilmiştir. Bu bölgenin mezarlık seçilmesinin sebebi, buranın yeşilliği, suyu bulunmayan çorak arazi olması, çok zor ulaşılabilmesi, insan ve hayvanların ayak basmadığı, yaşamdan oldukça uzak alanları kaplamış olması ifade edilmiştir. ${ }^{72}$

Krallar Vadisi'ne ilk olarak 1. Thutmose (تحتمس) 'nin anıt mezarını yaptırdığı bilinmektedir. Bu kralın, sıradağlardan bir tepenin arkasında film şeridi tarzındaki mezarı mevcuttur. Mezarın küçük bir girişi bulunur, buradan basamaklarla kare tarzı bir odaya inilir. Buranın orta kısmından aşağıya doğru defin odasına geçilir. Defin odasının son kısmında kuvars taşından yapılmış bir tabut bulunur. ${ }^{73}$

Krallar vadisine en geç olarak 20. Hanedanın son kralı 3. Ramses'in oğulları 10. Ramses ile 11. Ramses defnedilmiştir. Bu vadide 63 adet mezar olduğu belirtilse de sadece bina kırıntıları kalmıştır. Kırıntılardan bu mezarların dışının kireç taşından yapıldığı anlaşılmaktadır. Duvarlarına da Antik ve Orta Mısır'dakinden farklı olarak hiyeroglif yazılar yazılmış, sanat, çiftçilik, avcılık gibi günlük hayatla ilgili resimler yapılmıştır. Bunların yanı sıra ölen kişiyi diğer alemde korumak amaçlı silah, tılsım, geyik ve manda başından yapılmış muska gibi şeyler duvarlara konulmuştur. ${ }^{74}$

Eski Mısır'da mezarın mimarisi, büyüklüğü, görkemi ile öldükten sonraki hayatta mutluluk vesilesi olduğuna inanılırdı. Buna göre kişinin mezarı ne denli

9 bk. Hasan, Mevsû'atu Mıșri'l-kadîme, 3/34.

70 bk. Şinnâvi, el-Ma'bed ve'l-cebbânetu fi Mıșri'l-ḳadîme, 170.

71 Krallar Vadisi; Mısırın tarihi illerinden Luksor'un batı tarafında bulunmaktadır. 11.yy dan 20.yy la kadar krallar ve ailelerinin mezarlarının bulunduğu yerdir. bk. Vikipedi, "Krallar Vadisi" (Erişim 11 Haziran 2020).

72 bk. Carihi, "Merâhịilu tațavvuri şekli'I-maḳberati'I-melikiyyeti fî Mıșri'I-ḳadîme", 543. Bütün bu gayretlere rağmen kaya içlerindeki cesetlerin ve beraberindeki değerli eşyaların çalınması Yeni Kralıı^ta da önlenememiştir. bk. a. mlf. 544.

73 bk. Cârihî, "Merâḥilu tațavvuri şekli'l-maḳberati'l-melikiyyeti fî Mıșri'l-ḳadîme", 543.

74 bk. Cârihî, "Merâhilu tațavvuri şekli'l-maḳberati'l-melikiyyeti fî Mıșri'l-ḳadîme", 544; bk. Hasan, Mevsû'atu Mıșri'lkadîme, 1/93; bk. Vikipedi, "Krallar Vadisi". 
gösterişli olursa ölümden sonraki hayatında o denli mutlu olacağı kabul edilirdi. Bu sebeple firavunlar, ileri gelenler ve zengin olan herkes mezarlarını hayatta iken en güzel şekilde yapmaya çaba gösterirdi. Firavunlar, mezarlarının yapımını çeşitli sebeplerden dolayı tamamlayamadıklarında yerine gelen oğlu ya da varisi olan kişi kalan kısmı tamamlardı. ${ }^{75}$

İşçiler, çiftçiler, hamallar, mezar çalışanları, su işlerini yapanlar gibi topluma hizmet görevini yerine getiren fakirlerin bu tür mezar yapma imkanları olmadığından onların durumları farklıydı. Bunlar umumi mezarlara gömülürdü. ${ }^{76}$ Fakir kişinin cesedi ketenden kumaşa sarılır, üzerine de biraz kum serpilerek tabutlu ya da tabutsuz mezara yerleştirilir, üzerine aynı şekilde başka ceset konulurdu. Üst üste konulma işlemi tavana varıncaya kadar devam ederdi. Mezarların üzerine hizmet ettiği efendisinin ismi yazılır, böylece efendisi zengin ya da vezir gibi saygın biri ise öbür alemde de ona hizmet etme lütfuna erişmiş olurdu. ${ }^{77}$

Öte yandan mezarın yanı sıra cesedin kokuşmaması, bozulmaması, sağlam kalmasının da ölümden sonraki hayatta mutluluk gereği olduğuna inanılırdı. Bu sebeple cesetleri mumyalar ve onların hırsızlar tarafından çalınmaması ya da zarar görmemesi için gerekli önlemleri alırlardı. Bu önlemler arasında en önemlilerden biri de mezarlığın korunaklı olması, görevli kişiler tarafından güvenliğinin sağlanması ve hırsızların ulaşamayacağı gözlerden ırak yerlerde olmasıydı. ${ }^{78}$

Mumyalama önemli kişilerin yanı sıra sıradan insanların cesetlerine de uygulanmıştır. Firavunlar, ileri gelenler ve zengin kişilerin mumyalanmaları iç organlarının, beyninin çıkarılması gibi detaylı şekilde yapılırken fakirlerinkine aynı derecede önem verilmemiştir. Onların mumyalanmasında karınlarının açılarak mide, bağırsak gibi iç organları çıkarılmamış, cesetlerine ardıç ağacının meyvesinden yapılan sıvı arka kısımdan enjekte edilerek potasyum nitrat ile tuzlanmıştır. Bu mumyalama sayesinde cesetlerin yüzyıllar boyu korunması sağlanmıştır. ${ }^{79}$

Ölüler mezarlara ilerideki yaşamlarında yardımcı olacağı fikriyle yiyecek, içecek, para, madeni süs eşyaları, ok, zincir, bilezik, küpe, yüzük gibi takılar, cenaze yemeğinden kalan kemikler ve bazı dini sembollerle birlikte yerleştirilirdi. Bunların yanı sıra yiyeceklerde kullanmaları için toprak tabak, bardak ibrik gibi

75 bk. Şinnâvi, el-Ma'bed ve'l-cebbânetu fi Mıșri'l-ḳadîme,170.

76 Luksor'un batı kısmında bulunan Tıbe mezarlığı gibi; yine Asasif denilen bölgede zenginlere ait mezarları arasında fakirler mezarlığı bulunmaktadır. Bk. Şinnâvi, el-Ma'bed ve'l-cebbânetu fi Mıșri'l-Kadîme, 241.

77 bk. Şinnâvi, el-Ma'bed ve'l-cebbânetu fi Mıșri'l-kadîme, 241.

78 bk. Şinnâvi, el-Ma'bed ve'l-cebbânetu fi Mıșri'l-kadîme, 266-267.

79 bk. Şinnâvi, el-Ma'bed ve'l-cebbânetu fi Mıșri'l-ḳadîme, 241. 
yaşam için ihtiyaç duyabilecekleri her şey hatta köpek $^{80}$, at gibi hayvanlar da mezara konurdu. ${ }^{81}$

Piramitlerin yanı sıra Mısır'a gidenlerin ilgisini çeken ve şaşkınlıklarına yol açan esrarengizliklerinden biri de mezar evlerdir.

\section{Mısır'ın Mezar Evleri}

Firavunlardan sonra Hristiyanların gelmesiyle Mısırlıların ölü gömme gibi pek çok adetlerinde önemli bir değişiklik olmamıştır. Bu durum İslam'ın gelmesine kadar devam etmiştir. 640 yılında Amr b. As tarafından Mısır'ın feth edilmesiyle birlikte, defin işlemlerini yerine getirmek, kabirlerde Kur'an okumak ve mezarlıkların bakım işlerini yapmak için buralarda vakıflar kurulmuştur. Vakıfların yanı sıra ölen kişinin namazını kılmak, ona dua etmek için mescitler yapılmıştır 82. Daha sonra vakıflar tarafından ilmi tahsil yapan öğrencilerin kalabilecekleri mekânlar inşa edilmiştir. Bunların yanı sıra mezarlıklardaki boş alanlara, ölen kişilere yakın olmak amaçlı akrabaları, sevenleri tarafından ikamet edilen evler yapılmıştır. ${ }^{83}$

Mısır'a hakim olan Fatimiler (969-1171) zamanında mezarlıklara çok önem verilirdi. Özellikle ramazan aylarında ölülere Kur'an okumak, dua etmek için mezarlık yakınlarında çadırlar kurulurdu. Bu çadırlarda ramazan boyu kalınırdı, yemekler verilirdi, ibadet edilirdi. Çadırlar kandiller, mumlarla ışıklandırılırdı. Ramazan ayının yanı sıra dini bayram gibi önemli günlerde de buralara gelinir kalınırdı. Mesela vefat olayının ertesi ya da 3. Günü insanlar buralarda toplanırdı, yemek verirdi, sadaka dağıtırdı. Bu adet kısmen günümüze kadar devam ettirildi. ${ }^{84}$

Fatimiler'den sonra Mısır'da yönetimi ele geçiren Eyyubiler (1171-1250) zamanında da mezarlıklara verilen önem devam ettirilmiş; ayrıca buralarda sufiler, abidler, fakirler, yetimler, evsizler gibi ihtiyaç sahiplerinin sürekli olarak kalabilmeleri için yerler yapılmıştır. Eyyubilerin son zamanlarında bazı ekonomik, kültürel ve sosyal sebeplerden dolayı eğitim almak, mezarlık bakımını sağlamak gibi işler için buralardaki vakıflar çoğalmış, buna bağlı olarak mezarlıklarda kalan insanların sayısı da gittikçe artmıştır. ${ }^{85}$

Eyyubiler'den sonra Mısır'da idareyi ele alan Memluklar (1250-1517) döneminde de mezarlıklara önceki dönemlerde verilen önem devam ettirilmeye çalışılmıştır. Bu dönemin son zamanlarında ekonomik durumun gittikçe

80 Köpek, Mıser'da savaşlarda kullanılan önemli bir hayvan idi. Bk. Hasan, Mevsû'atu Mıșri'l-ḳadîme, 3/57-58.

81 bk. İbrahîm Amîrî-Suzân Revbe, el-Medâfin ve'ț-țugûsi'l-cenâ'iziyyeti fi 'usuri'l-klâsîkiyyeti fî rîfi Dimeşk (Dimeşk/ Suriye: Vizâretu's-Sakâfe, 2012), 23-28; bk. Hasan, Mevsû'atu Mıșri'l-ḳadîme, 1/93-94. Eski Yunanlılar'da da aynı şeyler görülmektedir. Amiri-Revbe, el-Medâfin ve'ț-țugûsi'l-cenâ'iziyyeti fi 'usuri'l-klâsîkiyyeti fî rî́i Dimeşk, 29.

82 Mescit kelimesi, Türkiye'de günlük ibadetlerin yapılabildiği minaresiz, minbersiz küçük mekânlar için kullanılırken, Mısır'da camiler için kullanılmaktadır.

83 bk. Mahmûd Muhammed el-Câd, Sekenî'I-meKabir fi'I-Kâhira, (Kahire: el-Muellif, 1992), 33-40.

84 bk. Câd, Sekenî'l-meḳabir fíl-Kâhira, 37.

85 bk. Câd, Sekenî'l-meḳabir fi'l-Kâhira, 40-41. 
zayıflaması ile yöneticiler bazı vakıflara el koymuş, bazılarının giderleri de mezarlık sahiplerine bırakılmıştır. Bu durum bir kısım vakıfların gittikçe ihmal edilmesine, zamanla da yok olmasına yol açmıştır. ${ }^{86}$

1517 yılında Yavuz Sultan Selim'in Mısır'a hakim olmasından, Fransızlar tarafından (1799-1805) işgal edilmesine kadar geçen sürede mezarlara verilen önem, önceden olduğu gibi devam ettirilmiştir. Bu işgal, Mısır'da pek çok şeyde olduğu gibi mezarların durumunda da önemli değişikliklere sebebiyet vermiştir. Fransız işgaline direnen -isyancı olarak isimlendirilen- kişilerin saklanma ihtimaline karşılık mezarlıklardaki büyük binalar, pek çok ağaçlar, surlar yıkılarak, yerle bir edilmiştir. Daha sonra yönetimi ele geçiren Muhammed Ali ${ }^{87}$ zamanında bu mezarlıklarda yapılan mescit/cami gibi yerlerde dini eğitim verilmekte iken daha sonra bu görev camilerden alınarak yeni yapılan okul ve üniversitelere verilmiştir. ${ }^{88}$ Bütün bu değişikliklere rağmen bazı kişiler yine de mezarlıklarda hayatlarını sürdürmeye devam etmiştir. ${ }^{89}$

İçerisinde hayatın devam ettirildiği mezar evler, Mısır ile özleştirildiğinden dolayı "Mısır'ın Mezar Evleri" olarak tanımlandığını söyleyebiliriz. Bunlar sadece Kahire'de bulunmaktadır. Artan nüfusla birlikte Kahire'de benzer tarzda başka mezarlıklarda yapılmışsa da buralar konut olarak kullanılmamaktadır. Bu açıdan Kahire'deki mezar evleri, konut olarak kullanılanlar ve kullanılmayanlar şeklinde tasnif edebiliriz.

Kahire'deki mezar evler bölgesi üç grupta sınıflandırılabilmektedir; ${ }^{90}$

1. Grup, şehrin güneydoğusunda yer alır. Burası güneyden kuzeye doğru Besatin, Tunisi, İmam Lisi, Seyyid Ebu Vefa, Seyyid Şatibi, İmam Şafii, İbnu Farid, Memalik ve Seyyide Nefise bölgesidir. Doğuda Mukkaddam Dağı tepeleri, batıda Aynu's Sire tepeleri ve boş alanlar yer alır. Bu grup idari olarak el-Halife kısmına bağlıdır.

2. Grup, şehrin doğu kısmının ortasındadır. Burası güneyden kuzeye doğru kalenin doğusunda bulunan Babu'l Vezir, Mucavirin, Kayıtbay, Gafir ve Babu'n Nasr mezarlıklarının sıralandığı bölgedir. Kuzeyde Tarik Salah Salim, güneyde Nasr Tesisi ve Mukaddam Dağı yer almaktadır.

3. Grup, şehrin kuzey doğusunda yer alır. Güneydoğuda Aynu'ş Şems mezarlığı, kuzeyde Ahmed İsmed Caddesi ve Medinetu'n Nasr, doğuda ise Hayyu's Sabi' yer almaktadır. Bu bölge diğerlerine göre daha yeni kabul edilir.

86 bk. Câd, Sekenîl'-mekabir fíl'-Kâhira, 45-46.

87 Muhammed Ali Paşa (1769-1849), Kavala doğumludur. 1805 tarihinde Mısır'a vali olarak tayin edilen bir Osmanlı paşasıdır. bk. Muhammed Hanefi Kutluoğlu, "Kavalalı Muhammed Ali Paşa", Türkiye Diyanet Vakfı İlam Ansiklopedisi (Ankara: TDV Yay., 2002), 25/62-65.

88 Bu sebeple Muhammed Ali tarihe geleneksel eğitimi değiştiren kişi olarak geçmiştir. bk. Câd, Sekenîl'-mekabir fíl-Kâhira, 49.

89 bk. Câd, Sekenî'l-mekabir fîl'-Kâhira, 47-50.

90 bk. Câd, Sekenî'l-mekabir fíl-Kâhira, 64. 
Alanda yapmış olduğum gözlem ve çalışmaların sonunda Kahire'de mezar evlerin çok büyük alanı kapladığı görülmüştür. Büyüklüğünden dolayı mezarlık alanları mahallelere ayrılarak farklı adlarla isimlendirilmişdir. Bu isimler mezarlardaki önemli kişilere ya da yakınlardaki mühim mekânlara atfen verilmiştir. İmam Şafi Mahallesi, Seyyide Zeyneb Mahallesi, Kayıt Bey, el-Besatin bu isimlerden bazılarıdır.

Mezarlıklar arasında coğrafi açıdan en önemlileri İmam Şafii ve Şarkiyye Müslim Mezarlığıdır. İmam Şafi Mezarlığı diğerlerine kıyasla en kalabalık olandır. Güneyinde Tunisi, doğusunda Şatibi ve Ömer İbni Farid, batısında 'Aynu's Sıra tepeleri ve boş arazi, kuzeyinde Memalik, kuzeybatısında Seyyide Nefise Mezarlığı bulunmaktadır. Şarkiyye Müslim Mezarlığı da gerek coğrafi konumu, gerekse yoğunluğu bakımından önemli mezarlar arasında yer almaktadır. ${ }^{11}$

Firavunlar zamanından günümüze Mısır'da defnedilen cesetlerin, mezarların korunması, hırsızlar, soyguncular tarafından zarar görmemesi için mezarlıklara çok önem verilmiş, bunun için gerekli tedbirler alınmıştır. Bekçi ya da polis gibi ehil kişiler tarafından buralar beklenerek korunmuştur. Bu bekçiler, ekonomik şartların zorluklarından dolayı buralarda daimi şekilde kalmaya başlamıştır. Daha sonra bu kişiler, bekçiliğini bakımını yaptıkları bu mezarların ön, arka ya da yan kısımlarına yaptıkları ilavelerle buraları kısmen ev hâline getirerek aileleriyle birlikte yaşamaya başlamıştır. Böylece Mısır'ın mezar evleri oluşmuştur. ${ }^{92}$

Mezar evlerin bulunduğu bölgelerde bizzat yapılan gözlem, görüşme ve incelemeler sonucunda şu hususlar tespit edilmiştir;

Mısır'da her akraba grubu ölüleri için mezar olarak üstten merdivenle inilebilecek yaklaşık beş metre derinlikte karşılıklı iki oda büyüklüğünde yer açar ve etraflarını da işlem görmemiş doğal taştan duvarla örerler. Merdiven iki odayı birbirine bağlayacak şekilde ortada oluşturulur. Bu odalardan soldaki ölen kadınlar, sağdaki ise ölen erkekler içindir. Kefenlenmiş ceset, cinsiyetine göre ilgili oda içerisinde gömülmeyerek zemine yerleştirilen taşlar üzerine konur. Konulduktan sonra kefenin bağları çözülür, merdiven sıkı bir şekilde toprakla kapatılır. Daha sonra aynı aileden biri öldüğünde kapatılan merdiven açılır erkek ise sağdaki kadın ise soldaki odaya önceki cesetlerin yanına konulur ve tekrar merdiven sıkıca kapatılır.

Toprak altında oluşturulan odaların tam üst hizaları boş bırakılacak şekilde dört tarafı duvarlarla çevrili penceresi kapısı olan üstü kapalı ev şeklinde yapılır. Kapı üzerine yerleştirilen bir kitabeye mezarlığın ait olduğu ailenin ismi yazılır. Bu şekilde her ailenin ya da akrabanın kendilerine mahsus kabristanı mevcuttur. Zamanla dolan ve yeni bir ölüyü yerleştirme durumu olmayan odalarda bulunun

91 bk. Câd, Sekenî'l-meḳabir fíl-Kâhira, 65.

92 bk. Şinnâvi, el-Ma'bed ve'l-cebbânetu fi Mıșri'l-ḳadîme, 264. Mezarlıklarda yaşayanlardan bizzat edindiğim bilgilerdir. 
kemikler toplanarak açılan bir çukura gömülür. Bu çukur genelde aynı oda içerisinde açılmakla birlikte bazen de başka bir kııımda açılarak üzerine ailenin ismi yazılır ya da yazılmaz. Bu kısmın kapı ve penceresi sadece gerektiğinde açılır ve sonra pencere kapatııır, kapı ise kilitlenir. Bu evin duvarları yer altında oluşturulan oda mezarların etrafını da kapsayacak şekilde yapılır; ancak bu kısmın üstü kapatılmaz. Böylelikle oda mezarların üzerine yağan yağmura engel olunmasa da kedi köpek gibi hayvanların girmesi önlenmiş olur. Mezarların bu şekildeki mimari yapısı kişilerin buralarda yaşamasını mümkün kılar.

Mezarlara bitişik olarak yapılan yer üstü ev tipi binalar, gerek mezar ziyaretleri gerekse mezardaki ölüler için Kur'an okumak, yemek ikram etmek için gelindiğinde oturma amaçı yapılmaktadır; zira İslam inancı gereği mezar üstüne oturmak uyumak -daha önce belirttiğim gibi- uygun değildir.

Muhammed Ali Paşa zamanında kabir bölgesinde oturan insanların adedi sınırlı idi. Mezar evlerde oturanlar kabirlerdeki cami, türbe gibi yerlerin hizmetini yapan, mezar kazıcılar, bazı sufiler ve buralarda dağıtılan sadakalar, kurban ve adaklarla hayatlarını idame ettirin fakir kişilerdi. Bir de Mukaddem Dağı'nda taş kırma, kireç ve kum çıkarma gibi işlerde çalışanların bir kısmı da buralarda kalmaktaydı. Daha sonraki dönemlerde ise ekonomik, iskan, sosyal, güvenlik gibi farklı sebeplerden dolayı mezar evlerde yaşayanların sayısı sürekli olarak artmıştır. ${ }^{93}$

1856, 1857, 1871 yıllarında devlet, resmi belgesi olmayan arazilere tapu verilmesini kararlaştırmıştır. Bu kanundan faydalanmak isteyen kişiler, gereken ücreti çalışarak temin edebilmek için farkı ıölgelerden Kahire'ye gelmiş ve çoğu iskan yeri olarak mezarlıkları seçmiştir. Bunun yanı sıra devlet, bazı mezarlıklarda kendi memurlarının oturması için evler yapmıştır. Bu sebeple özellikle Kayıtbay, el-Garib ve'I Mucavirin ve İmameyn bölgelerinde ciddi artışlar olmuştur. ${ }^{94}$

1882 yılında İngilizlerin Mısır'ı işgal edip mezhep kavgalarını kışkırtmasıyla bir kısım halk kendileri için daha güvenli bölge olarak gördükleri kabir bölgelerine sığınmıştır.95

1927-1937 yılları arasında devlet çıkardığı kanunla vatandaşları buralarda oturmaya teşvik etmiş bu da buralara önemli miktarda göç gelmesine yol açmıştır. Mezarlıklara olan bu göçler sonraki yıllarda da sürekli devam etmiştir. Mesela Besatin bölgesinin nüfusu, 1960 yılında 1450 iken 1976 senesinde hemen hemen yılda \%27,3 oranında artış ile bu rakam 75461'e ulaşmışıı. Bu artışlar neticesinde 1980 'li yılların ortasında mezarlıklarda yaşayan insanların sayısı yüz binlere ulaşmıştır. ${ }^{96}$

93 bk. Câd, Sekenîl'-mekabir fíl-Kâhira, 78.

94 bk. Câd, Sekenî'l-mekabir fi'l-Kâhira, 82,89.

95 bk. Câd, Sekenî'l-mekabir fíl-Ḳâhira, 76.

96 bk. Câd, Sekenî'l-mekabir fíl-Kâhira, 75,82. 
1940'lı yıllarda sürekli artan nüfusa karşı kısıtlı iş imkanları ve iskân gibi ciddi problemler yaşayanların mezarlıklarda ücretsiz ya da az fiyatlarla oturacak yer bulmaları, Mısır'ın farklı bölgelerinden insanların mezarlıkları yerleşim yeri olarak benimsemelerine yol açmıştır. Bunları, fakirlikten dolayı ya köylerinden gelenler ya da Kahire'nin farklı bölgelerinden olup oturdukları evlerin mecburi onarımını yapamama gibi farklı sebeplerle evsiz kalanlar oluşturmuştur. ${ }^{97}$

Köylerden fakirlik sebebiyle göçler en fazla II. Dünya Savaşı sırasında olmuştur. Savaş sebebiyle başta soğan, pamuk olmak üzere Avrupa'ya ihracat durmuş, yine ziraatte kullanılan suni gübre, lüzumlu böcek ilaçları gibi maddelerin ithali yapılamamış; bu da köylüyü şehre göç etmeye zorlamıştır. 1967 Arap-İsrail savaşında yaşanan hezimetten dolayı Süveyş Kanalı gibi savaş bölgelerinden de mezarlıklara yoğun göçler olmuştur. ${ }^{98}$

Sırf şehrin kalabalığından uzak kalmak için mezarlıklar bölgesinde oturmayı tercih edenler olduğu gibi, mezarlıkların etrafı surlarla çevrili olup bekçileriyle birlikte güvenli bölge intibası vermesi sebebiyle yaşamak için tercih edenler de olmuştur. Bunların yanı sıra Nasır (1918-1970) ${ }^{99}$ zamanında buralara su, elektrik, eğitim, temizlik hizmetleri götürülmüş, güvenlik merkezleri kurulmuştur. Bunlar da mezarlıklara yönelmeyi artırmıştır. Bazıları da mezarlıklara yakın yerlerde iş bulmuş, bu sebeple oturmak için mezar evleri tercih etmişlerdir. Diğer taraftan mezarlıkların merkezi yerlerde -cadde üstü, ulaşımı kolay- olması da buralarda oturmayı cazip kılmıştır. ${ }^{100}$

Mezarlıklarda yaşamını sürdürenlerin az bir kısmı da eski paşa, ya da beylerine ait mezarların bakımını yapmak, mezarın güvenliğini sağlamak için buralarda ailece yaşayan kişilerdir. Bunların yanı sıra para istemek/dilenmek, polisiye vakalar sebebiyle saklanmak, uyuşturucu ticareti gibi yasak işler yapmak amacıyla buralara yerleşenler de olmuştur. ${ }^{101}$

Yukarıda sayılan sebeplerle birlikte mezarlıklara göçlerin çoğunlukla fakirlikten kaynaklandığını söyleyebiliriz.

Mezarlıklara göçler 1970-1974 yıllarına kadar devam etmişse de bu yıllardan sonra bazı sebeplerden dolayı azalmıştır. İhtiyaç sahiplerinin önemli bir kısmı çalışmakiçin petrol ülkelerine gitmiş ve kazandıklarını köylerinde değerlendirmeyi tercih etmiştir. Bunun yanı sıra devletin, köylerde okul gibi eğitim kurumları, sağlık merkezleri gibi istihdam alanları inşa etmesi, savaş sebebiyle köylerden

97 bk. Câd, Sekenî'l-meḳabir fíl-Kâhhira, 98-100.

98 bk. Câd, Sekenî'l-mekabir fî'l-Kâhira, 101-102.

99 Asıl adı Cemal Abdulnasırdır. Mısırın ikinci cumhurbaşkanıdır. Devrimci, milliyetçi ve sosyalist bir liderdir. Arap dünyasında önder rol oynamıştır. bk. Biyografi.info, "Cemal Abdulnasır Kimdir" (Erişim 20 Nisan 2019). Bu sebeple Mısırlılar ve Arapların ekseriyeti tarafından çok sevilmekte, ismi özlemle ve saygı ile anılmaktadır. (Saha araştırmam.)

100 bk. Câd, Sekenî'l-meḳabir fíl-Kâhira, 75-77, 83, 88-109, 117.

101 bk. Câd, Sekenî'l-meḳabir fíl-Kâhira, 98-99. 
şehirlere göç edenlerin bir kısmının buralarda karşılaştıkları zorluklardan dolayı barış sağlandıktan sonra tekrar eski topraklarına geri dönmesi bu azalmada rol oynamıştır. ${ }^{102}$

Mısır İstatistik Merkez Ajansının verdiği bilgilere göre mezar evlerde 5 milyon kişi yaşamaktadır. Bunlardan 1.6 milyonu Kahire, Giza, Kalubiyye gibi büyük bölgelerde yaşamaktadır. Yaşayanların adedinin gittikçe arttığı bu bölgelerde nüfusun 2030 senesinde 10 milyona ulaşacağı tahmin edilmektedir. Burada yaşayanlar ilaç, yiyecek-içecek temin etmekte problem yaşamaktadırlar. ${ }^{103}$ Hatta bazılarının evlerinde, su, elektrik bulunmamaktadır. Elektriğin olmayışı özellikleri geceleri güvenlik açısından, suyun olmayışı da hijyen açısından tehlike oluşturmaktadır. Sokaklarda yeterli ölçüde ticari dükkanlar bulunmamakta, zaruri ihtiyaçların karşılanmasında zorluk çekilmektedir. İş imkanlarının az olduğu bu bölgelerde, kişiler çoğunlukla şehrin başka yerlerinde çalışmaktadır. ${ }^{104}$

Çoğunluğunu Kıptilerin oluşturduğu Mısır Hristiyanları ${ }^{105}$ ile Müslümanlar arasında sosyal yaşantı açısından görünürde bir farklılık yok gibi olsa da mezar konusunda inançtan kaynaklanan farklılıklar bulunmaktadır. Kahire'deki mevcut bu iki farklı din mensuplarının mezarları ayrı mekânlarda bulunmakta ve Hristiyanlar mezarlarını ev olarak kullanmamaktadır. Mezar evlerde yaşamını sadece Müslümanlar sürdürmektedir. ${ }^{106}$

Mezarlıklarda yaşayan halk, demografik, fiziki, ekonomik ve sosyal yapısıyla Kahire'nin diğer bölge sakinlerinden nispeten farklıdır. Bu farklılığı bizzat yerinde tespit etmek için Kahire'nin Mukaddem (مقطم) Dağı eteklerinde yer alan Kayıt Bey mezarlığı sakinlerinden biri olan Muhammed Fervari rehberliğinde buraya bir ziyaret gerçekleştirdik. Ziyaretimiz esnasında mezarlığın en eski sakinleri ile tanıştık ve kendilerinden konu ile ilgili önemli bilgiler aldık. Bilgi edindiğimiz kişilerden biri Ümmü Sultan lakaplı, Semira Fethi Abdul Aziz idi. Ümmü Sultan 60' Iı yaşlarda aslen İskenderiyeli olup burada yaşayan bir aileye 16 yaşında iken gelin olarak gelmişti. $\mathrm{O}$, şimdi çocukları ve torunları ile birlikte burada yaşıyor, ayrıca ufak bir bakkal işletiyordu. Eşinin ailesinin 700 yıldır burada yaşadıklarını, hatta bulundukları caddenin onlardan dolayı Sultan ismini taşıdığını ifade ediyordu.

Çocuklarının farklı mesleklerde çalıştığını söyleyen Ümmü Sultan, ziyarete gelenlerden para istediklerini, verilenin Allah katından rızıkları olduğunu ve bunun utanılacak bir şey olmadığını rahat bir şekilde anlattı. Ümmü Sultan

102 bk. Câd, Sekenî'l-mekabir fí'l-Ḳâhira, 103-104.

103 bk. Ra'i'l-yevm, “5 melâyin muvâțin Mıșrî 'eḥyâ'i ye'îşûne fíl-meḳâbir” (21 Nisan 2020). Ra'i'l-yevm; Mısır'da çıkan bir gazetedir.

104 bk. Câd, Sekenî'l-meḳabir fi'l-Ḳâhira, 121-122.

105 2017'de kilise tarafından yapılan açıklamalara göre Mısırlı Hristiyanların adedi 15-18 milyondur. Resmi makamlar tarafından yapılan açılamaya göre ise Hristiyan nüfusu 5.1 milyondur. Bu açıklama Kilise tarafından siyasi bulunmuş ve tartışmalara yol açmıştır. bk. Hamdî Rizki, “Kem 'adedu'l-'aḳbaț fî Mıșır”, el-Mıșru'l-yevm, (03 Ekim 2017). Mısır'da çıkan günlük gazetelerden biridir.

106 Saha araştırmam. 
buradaki görevlerinin aile kabristanını korumak, bakım ve onarımını yapmak olduğunu ve buralarda oturanların İskenderiyye, Said, Beni Suveyf, Menyal, Kalubiyye gibi farklı bölgelerden geldiğini, evlilik oranının şehirdekilerden çok daha yüksek olduğunu, çocuk yapmaya önem verildiğini bu sebeple de nüfusun sürekli arttığını, aynı sokakta oturan ailelerin çoğunlukla birbirleriyle akraba olduklarını, bunun da aralarında sıkı ilişkiler gelişmesine katkı sağladığını belirtti. Diğer taraftan bu hanım ve rehberim olan Muhammed Fervari eğitim seviyelerinin düşüklüğünü hatta okur yazar oranın -gençler ve çocuklar dışındaaz olduğunu kaygılı bir şekilde ifade ettiler.

Mısır, Müslümanlar tarafından feth edildikten sonra mezarlıklarda daha ziyade ilim tahsil edenler, mutasavviflar, fakirler, evsizler, gidecek yeri olmayan yabancılar, mescit, türbe gibi dini müesseselerin işlerini yürütenler, mezar kazıcılar, defin işlemlerini ve mezarların bakımını yapan bekçiler yaşamıştır. Daha sonra mezarlıklar bölgesinin merkeze yakın oluşu sebebiyle Mukaddam Dağı'ndaki taş ocağı, maden ocağı ve inşaat işlerinde çalışanlar, müteahhitlik yapanlar, hurdacılar gibi aslen mezarlık işleri ile ilgili olmayanlar da buralarda yaşamaya başlamıştır. ${ }^{107}$

Belirtilen sebeplerle mezarlıklarda zamanla artan nüfus ile birlikte çevre alanlara dokuma tezgahları, sanat atölyeleri, bazı küçük sanayi faaliyetleri kurulmuştur. Bu faaliyetler arasında ağaç kesme/doğrama, mobilyacılık, kaynak, sıhhi tesisat, çivi yapım, kesim, törpü, deri ve ayakkabı yapım atölyeleri, nakış sanatları yer almıştır. Daha sonra kentlerdeki yığılma nedeniyle mezarlıklar bölgesi bu tür meslekler için adeta sanayi bölgesi haline gelmiştir. ${ }^{108}$

Pek çok mesleklerle birlikte mezarlıklarda yaşayanların ekseriyeti, ücret karşıı̆̆ı içerisinde yaşadıkları mezar binaların temizliğini yapmak ve mevcut ölüleri korumakla görevlidir. Bu kişilere mezardakilerin yakınları tarafından çok cüzi ücretler ödenmektedir. Burada yaşayanların çoğu gerek mezarlığa ziyarete gelenlerden gerekse yollarda para isteyerek geçimlerini sağlamaktadır. ${ }^{109}$

Mezarlıklar bölgesinin halkın güvenliği açısından da tehlike arz ettiği belirtilmektedir. Mezarlıklar Genel Müdürü Mühendis Taha Muhammed ile elMısriyyu'l Yevm (المصري اليوم) gazetesinin yaptığı röportajda bu bölgenin her tür suçun işlendiği zorbalıklar bölgesi haline geldiği, uyuşturucu çetelerinin burada yuvalandıkları, özellikle Nasr, Zeynel Abidin, İmam Şafii ve Tunusi kapılarında yoğunlaştıkları belirtilmektedir. Bu röportajda aynı zamanda iskan olarak kullanılan bu tür mezarların dünyada başka hiçbir yerde olmadığı, devletin burada

107 bk. Câd, Sekenî'l-mekabir fíl-Kâhira, 86-89.

108 bk. Câd, Sekenî'l-mekabir fi'l-Kâhira, 85-86.

109 Bu kişiler mezarlığa ziyarete giden kimseleri para talep etmede bunaltacak derecede ileri gitmektedirler. Mısırda yaşayan biri olarak gerek eşimin ailesinin kabirlerini ziyaret etmek gerekse Mısır dışından gelen misafirlerimizi gezdirmek için gittiğimizde, bu kişilerin üzerimize adeta hücum ettiklerini birkaç kez yaşamış bulunmaktayım. 
oturanları çıkarmak istediği; ancak onlar için başka uygun bir yer göstermedikçe bunun çok zor olacağı ifade edilmektedir. ${ }^{110}$

Mezar evlerde yaşayanların bir kısmı, buralarda bizzat mezar sahiplerinin izni ile, bir kısmı da sahipsiz mezarların bakımı için vakıflar idaresinin onayı ile oturmakla birlikte, izinsiz iskan eden pek çok aile bulunmaktadır. Bununla birlikte mezarlıklar bölgesi, şehir merkezinde bulunduğundan, burada oturanlar her an evlerinden çıkarılma korkusu taşımakta, defin olaylarından başta çocuklar olmak üzere psikolojik olarak etkilenmekte ${ }^{111}$, şehrin diğer bölgelerinde oturanlar tarafından küçümsenmektedir. Bütün bunların etkisiyle huzursuz olan bu insanlar, sık sık birbirleriyle tartışmakta kavga yapmakta; küçümsenen çocuklardan bazıları eğitimlerini yarıda bırakmakta, çalışanların bir kısmı da işlerini terk etmektedir. Bazen de oturdukları yer öğrenildiğinde işveren tarafından işten çıkarılmaktadır. Bu sebeple buralarda yaşayanların çoğu, oturdukları yeri gizlemekte, adres beyanından kaçınmaktadır. Bu kişiler evlenme girişimlerinde de zaman zaman oturdukların yerden dolayı vazgeçilmeye varan problemler yaşamaktadır. ${ }^{112}$

Öte yandan diğer yerleşim yerlerine kıyasla mezarlıklarda yaşayanlar arasında psikolojik hastalıklar, hırsızlık, adam öldürme, bağımlılık ve dilenciliğin daha fazla olduğu da bir realite olarak ifade edilmektedir. ${ }^{113}$

\section{Anıt Mezarlarla Mezar Evlerin Karşılaştırılması}

1. Eski Mısır'da ölen kişinin cesedine hürmet edilmekte, öldükten sonra başka bir alemde yaşayacağına inanılmaktaydı. Bu sebeple cesetler muhafaza edilmek için yapılan mezarlara defnedilmekteydi.

Şimdi de -i̇slami usul gereği- aynı şekilde ölen kişinin cesedine saygı duyulmakta ve cenaze defin işlemi ile gömülmektedir.

2. Eski Mısır'da saygın olan kişiler için piramitler/anıt mezarlar inşa edilmekteydi.

Şimdi de devlet büyükleri ve bazı yöneticiler için anıt mezar yapılmaktadır.

3. Anıt mezarlar yer altı ya da yer üstü şeklinde olup yer altında olanlara merdivenle inilirdi ve burada birden fazla oda bulunurdu.

Şimdi de mezarın yer altı ve yer üstü olmak üzere iki kısmı bulunmaktadır. Cesedin gömüldüğü kısım yer altı olup buraya merdivenle inilmektedir. Yeraltında bir koridor, bunun sağında erkeklere mahsus bir oda, solunda da kadınlara mahsus solda bir oda yer almaktadır.

110 bk. Muhammed Abdi'l-Halık Mesâhil-Ibrâhim Mu'avvad, "Mudîru 'am cebbânâti'l-Ḳahira lâ bedîle litevfîri sekenin liehâl'i el-meḳabir ....., el-Mıșru'l-yevm (02 Nisan 2018). Mısır'da yaşayan biri olarak bu bilgilere vakıf bulunmaktayım.

111 Ölen kişilerin akraba sevenlerinin ağlamaları gibi sürekli olarak elem veren sahnelere şahit olmaktadırlar.

112 bk. Câd, Sekenî'l-mekabir fî'l-Kâhira, 124-126, 137-139.

113 bk. Câd, Sekenî'l-mekabir fíl-Kâhhira, 140. 
4. Anıt mezarlarda cesetler toprağa gömülmez, mumyalanarak tabut içerisine konulurdu.

Şimdi de cesetler kefenlenerek yer altında yapılan odalara toprak üzerine konulmaktadır.

5. Eski Mısır'da Fakirlerin cesetleri üst üste konulurdu.

Şimdi ise kişiler, zengin fakir ayrımı olmaksızın aynı oda içerisinde yan yana konulmaktadır.

6. Firavunlar zamanında mezarda ölü için kurban kesilir dağıtılırdı.

Şimdi de mezar evlerde yiyecek ve sadaka dağıtılmaktadır.

7. Firavunlar zamanında ölen kişinin gideceği alemde yiyecek, giyecek, silah, at gibi günlük hayat için gerekli her şeyi mezar içerisine konulurdu.

Şimdi ise ölüler mezarlara İslami usule göre sadece kefenleri ile konulmaktadır.

8. Firavunlar zamanında mezarlıklarda sadece görevli kişiler yaşardı.

Şimdi ise mezarlıklarda mezarlık işleri ile ilgilenenlerin yanı sıra bu işlerle hiç ilgisi olmayan farklı meslek sahibi, değişik işler yapan kişiler de yaşamaktadır.

\section{Sonuç}

Eski Mısır'da mezar, önce çukur, sonra kabir odaları, sonra bu odaların üstüne kum ya da çakıldan tümsekler yapma, sonra oda sayılarının çoğaltılması, sonra yer üstü set, en sonunda da basamaklar oluşturulmak suretiyle tam piramit şekline dönüştürülmüştür. Daha sonraki dönemlerde ise mezarlar, dağlara, kayalara oyulmuş; hatta mezarların yerinin belli olmaması için cesedin yıkandığı, hazırlandığı cenaze mabedleri, anıt mezarlardan ayrı hâle getirilmiştir.

İslam, Mısır'a geldikten ve halk Müslüman olduktan sonra mezar kültürünün oluşmasında, sosyal olgu olarak toplumların yapısında süregelen örf, adet ve geleneklerden etkilenilmiştir. Mısır'daki mezarları da bu açıdan değerlendirmemiz gerekmektedir.

Mısır'da hâlen sürdürülegelen cenaze defin usulünün İslami geleneklere uygunluğu tartışılmaktadır. Bir kısım ulema Mısır'daki gömme şeklinin caiz olmadığını söylerken, diğer bir kısım ise zaruretlerin yasakları caiz kıldığını belirtmektedir.

Mezarlıkların meskun mahal olarak kullanılması, firavunlar zamanının kültürel, siyasi, ekonomik ve sosyal şartları altında ortaya çıkmıştır. Bu durum, İslami dönemlerde de bazı vakıf ve eğitim müesseseleri desteğiyle sürdürülmüştür. Daha sonra Kahire'de mevcut mezarların bir kısmı eve dönüştürülerek mezar işleri ile hiç ilgisi olmayan kişiler tarafından iskan amaçlı kullanılmaya başlanmış ve bu durum gittikçe artarak günümüze kadar devam ettirilmiştir. 
Mısır'daki mezar evler bölgesi, çarşısı, sokakları, mahalleleri, otelleri, hanları, hamamları, caddeleri, yaya yolları, demir yolları, depoları, camileri/mescitleri,

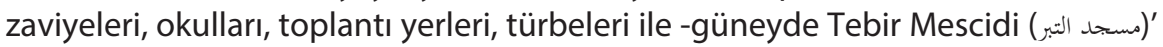
nden Vezir Besatin (بساتين الوزير)'e, Nil Nehrinden Mukaddam Dağı (الجبل المقطم)'na kadar uzanan- çok geniş bir alanı kaplamaktadır. Bu geniş alanda milyonlarca insan yaşamını sürdürmektedir.

Kahire'de mezarlarda /mezar evlerde kalabalık bir nüfusun yaşaması Mısır için halledilmesi gereken ciddi bir problem olarak değerlendirilmekte ise de çözümü kısa vadede oldukça zor görünmektedir. 


\section{Kaynakça}

Amîrî, İbrahîm-Revbe, Suzân. el-Medâfin ve'ț-țugûsi'I-cenâ'iziyyeti fí 'usuri'l-klâsîkiyyeti fî rîfi Dimeşk. Dimeşk/Suriye: Vizâretu's-Sakâfe, 2012.

Biyografi.info. "Cemal Abdulnasır Kimdir". Erişim 20 Nisan 2019. https://biyografi.net.tr.

Bozkurt, Nebi. "Mezarlık". Türkiye Diyanet Vakfı İlam Ansiklopedisi. 29/519-522. Ankara: TDV Yay., 2004.

Buharî, Muhammed b. İsmail el-. Sahîḥu'l-Buhârî. Nşr. Ahmed Muhammed Şakir. Kahire: Muessesetu Zâd, 1. Basım, 1433/2012.

Câd, Mahmûd Muhammed el-. Sekenî'l-meḲabir fíl- Kâhira. Kahire: el-Muellif, 1992.

Cârihî, Mahmûd Mursî Muhammed. "Merâhịilu tațavvuri şekli'l-maḳberati'l-melikiyyeti fî Mıșri'l-ḳadîme". Mecelleti'l-'imârati ve'l-funûn 10 (2018). 532-555.

Cubran, Mesud. er-Râ'id. Beyrut: Dâru'l-ilmu'l-melâyîn, 1. Basım, 2003.

Cuzeyrî, Abdu'r-rahman b. Muhammed 'Avad el-. el-Fıkhu 'al'a'l-Meżahibi'l-'Erbi'a. Mansura/Mısır: Daru'I-Gadi'l-Cedid, 1436/2015.

Demirci, Kürşat. "Cenaze". Türkiye Diyanet Vakfı İslam Ansiklopedisi. 7/353-354. İstanbul: TDV Yay., 1993.

Demirci, Kürşat. "Kabir". Türkiye Diyanet Vakfı İslam Ansiklopedisi. 24/33-35. İstanbul: TDV Yay., 2001.

Ebu Dâvud Süleyman b. el-Eş'as es-Sicistani. Süneni Ebî Dâvud. Nşr. Muhammed Nasiri'ddin Albani. Riyad: Mektebetu'I Mearif, 2. Basım, 1427/2007.

Hasan, Selîm. Mevsû'atu Mıșri'l-kadîme. ed. Semîr Serhân. 18 Cilt. Kahire: Mektebetu'I-'Usra, 2201-2017.

Heddar, Halid Muhammed Abdi'l-lah el-.Dirâsetu'l-kubûri'l-ferdiyye. 1 Cilt. Bingazi: Câmiatu Kâryûnis, 2006.

İbn Mâce, Ebi Abdi'llah Muhammed b. Yezidi'I-Kazvînî. Süneni ibn Mâce. Nşr. Muhammed Nasiri'd-din Albani. Riyad: Mektebetu'I Mearif, 2. Basım, 1429/2008.

İmam Kurtubi. el-Câmi'u li'aḥkâmi'I-Ḳur'an. çev. M. Beşir Eryarsoy. 20 Cilt. İstanbul: Buruc Yay., 1.Basım, 1997-2006.

Karaman, Hayreddin vd. Kur'an Yolu. 5 Cilt. Ankara: Diyanet İşıleri Başkanlığı Yay., 2012.

Kızılabdullah, Şahin. "Pre and Post-Death Rituals in Christianity: A Phenomenological Analysis", Türkiye Ilahiyat Araştırmaları Dergisi 3/1 (June 2019). 117-135.

Kitab-ı Mukaddes. İstanbul: Kitab-ı Mukaddes Şirketi, 1993.

Kur'an-ı Kerîm ve Açıklamalı Meali. çev. Ali Özek vd. Ankara: Türkiye Diyanet Vakfı Yay., 1993.

Kutluoğlu, Muhammed Hanefi. "Kavalalı Muhammed Ali Paşa”. Türkiye Diyanet Vakfı İlam Ansiklopedisi. 25/62-65. Ankara: TDV Yay., 2002.

Malik b. Enes. el-Muvațțâ. Haz. Yahya b. Yahya el-Lisi'l-Endulisî. Nşr. Muhammed b. Nasıri'd-din Albani. Kahire: Dâru ibni'l-Cevzî, 1. Basım, 2010.

Mesahil, Muhammed Abdi'l-Halık-Ibrahim Muavvad. "Mudîru 'am cebbânâti'l-Ḳahira lâ bedîle litevfîri sekenin liehâl'i el-meḳabir ......", el-Mıșru'l-yevm 02 Nisan 2018. https:// www.almasryalyoum.com. 
Müslim, Ebu Hüseyin b. el-Haccac el-Kuşeyrî en-Neysâbûrî. Șahịhu Müslim. Nşr. Muhammed b. Nasıri'd-din Albani. Kahire: Daru't-Takva, 1. Basım, 1434/2012.

Özterzi, Sevil. Anadolu'da Neolitik ve Kalkolitik Dönemdeki Mezar Tiplerinin ve Ölü Gömme Geleneklerinin Sosyokültürel Açıdan Değerlendirilmesi. Ankara: Ankara Üniversitesi, Sosyal Bilimler Enstitüsü, Yüksek Lisans Tezi, 2011.

Ra'i'l-yevm. "5 melâyin muvâțin Mıșrî 'eḥâa'i ye'îşûne fî́l-mekâabir" (21 Nisan 2020). www. raialyoum.com.

Rizki, Hamdi. "Kem 'adedu'I-'aḳbaț fî Mıșır".el-Mıșru'l-yevm (03.10.2017). https://www. almasryalyoum.com.

Şener, Mehmet. "Kabir" Türkiye Diyanet Vakfı İslam Ansiklopedisi. 24/35-37. İstanbul: TDV Yay., 2001.

Şinnâvi, Abdu'l-Azîz es-Seyyid eş-. el-Ma'bed ve'l-Cebbânetu fi Mıșri'l- Kadîme. Tanta/Mısır: Mațâbi' 'Abbâş, 1. Basım. 2005.

Taberî, Ebu Cafer Muhammed b. Cerir et-. Taberî Tefsîri. çev. Hasan Karakaya- Kerim Aytekin. 9 Cilt. İstanbul: Hisar Yay., 1996.

Temimî, Salih b. Mukbili'l- Useymi't-. Bed 'u'I- Kubûri'enva 'uha ve 'ahḲâmuha. Riyad: Daru'lFadıla, 1425/2004.

Tirmizi, Muhammed b. İsa et-. Süneni Tirmižî. Nşr. Muhammed b. Nasıri'd-din Albani. Riyad: Mektebetu'I-Mearif li'n-neşr ve't-tevzi', 2. Basım, 1429/2008.

Türkçe Etimoloji Sözlüğü, "Ehram”. Erişim 11. Mayıs 2020. https://etimolojiturkce.com.

Uzunpostalcı, Mustafa. "Defin". Türkiye Diyanet Vakfı İslam Ansiklopedisi. 9/86. İstanbul: TDV Yay., 1994.

Vikipedi. "Mastaba”. Erişim 13. Haziran 2020. ar.m.wikipedia.org.

Vikipedi, "Krallar Vadisi". Erişim 11. Haziran 2020. tr.m.wikipedia.org.

Yılmaz, Derya. "Erken Tunç Çağı'nda Güney Doğu Anadolu'da Oda Mezar Geleneği". Anadolu 31 (2006), 57-69. 
Ek.

Araştırma ve Gözlem Alanlarında Çekmiş Olduğum Resimler.

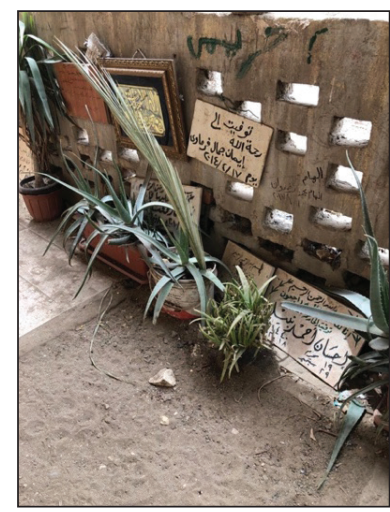

Alttaki Mezar Odalarda Bulunanların İsimleri

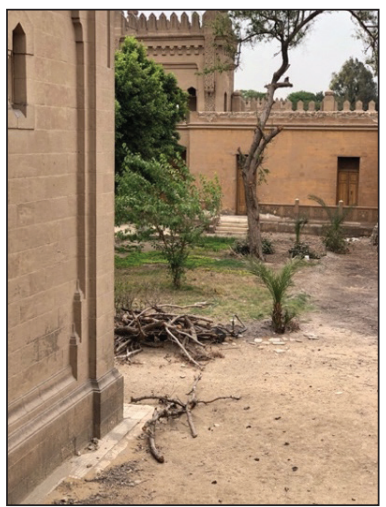

Mezar Ev Avlusu

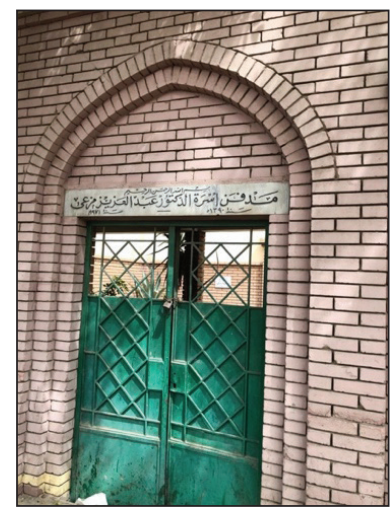

Mezar Ev Kapısı Üzerinde Ait Olduğu Ailenin İsmi

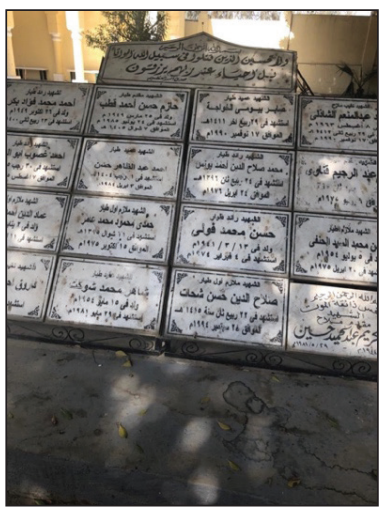

Alttaki Mezar Odalarda Bulunanların İsimleri

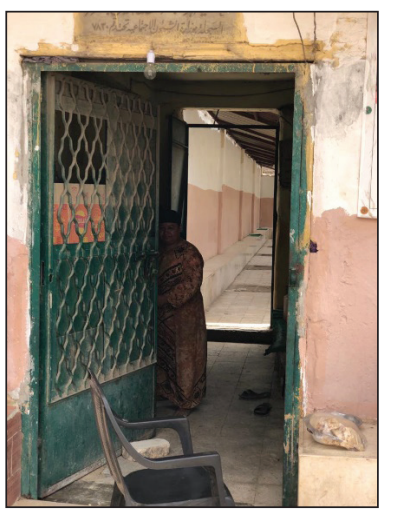

Mezar Ev Girişi

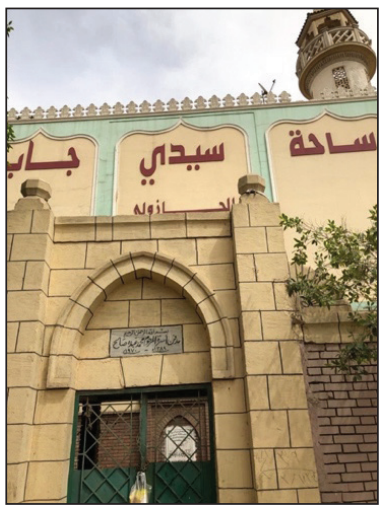

Mezar Ev Kapısı Üzerinde Ait Olduğu Ailenin İsmi

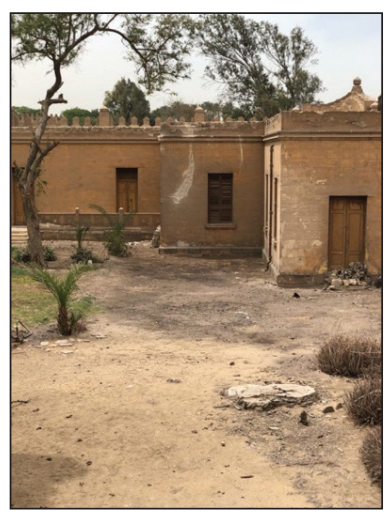

Mezar Ev Avlusu

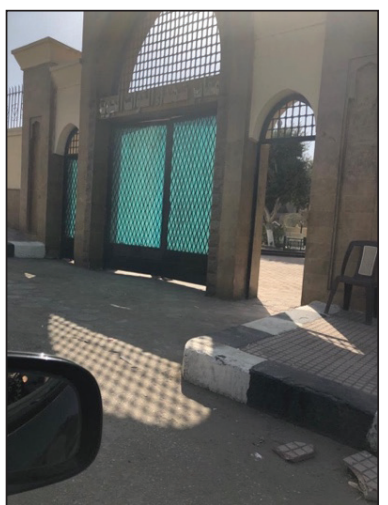

Mezar Ev Girişi

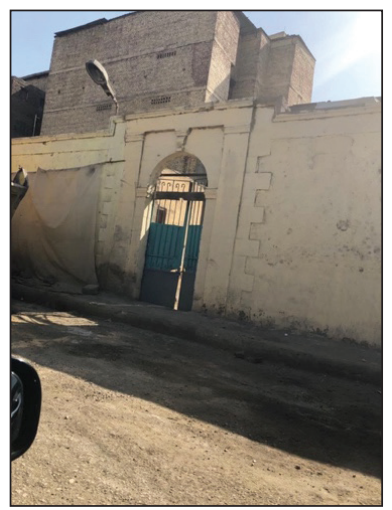

Bir Mezar Evin Dıştan Görünüşü

Journal of Theology Faculty of Bulent Ecevit University, Vol. 7, No. 2, 2020 


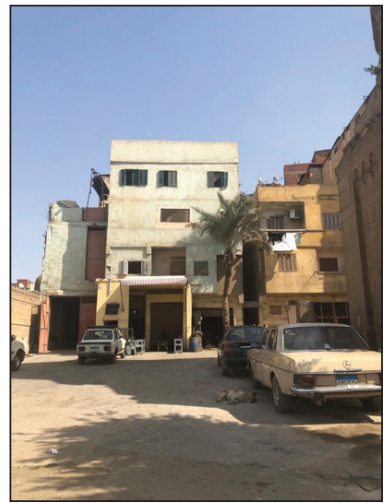

Katlı Binaya Dönüştürülen Mezar Evler

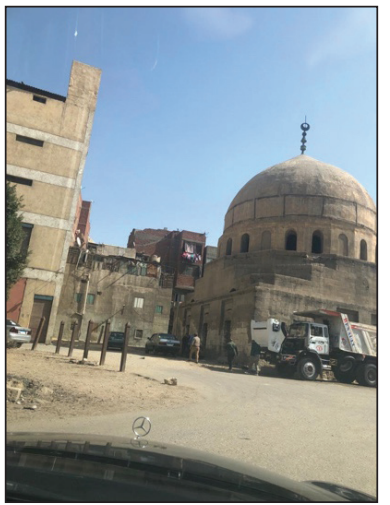

Mezar Evlere Ait Bir Cami

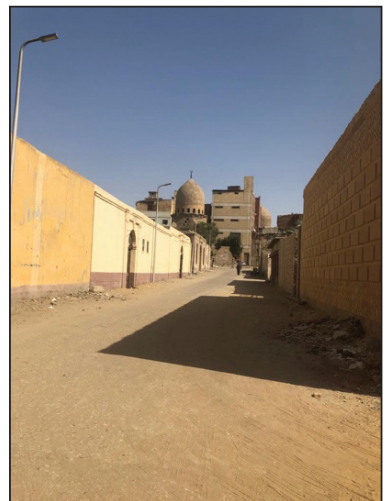

Mezar Evler Bölgesinden Bir Sokak

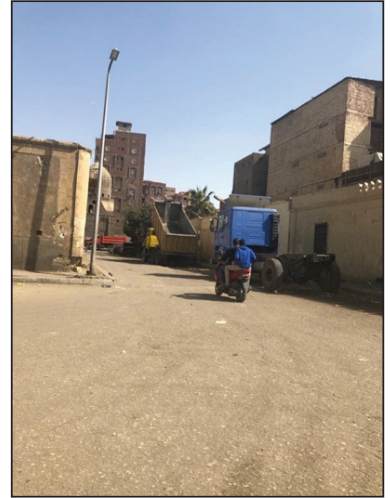

Mezar Evler Bölgesinden Bir Sokak

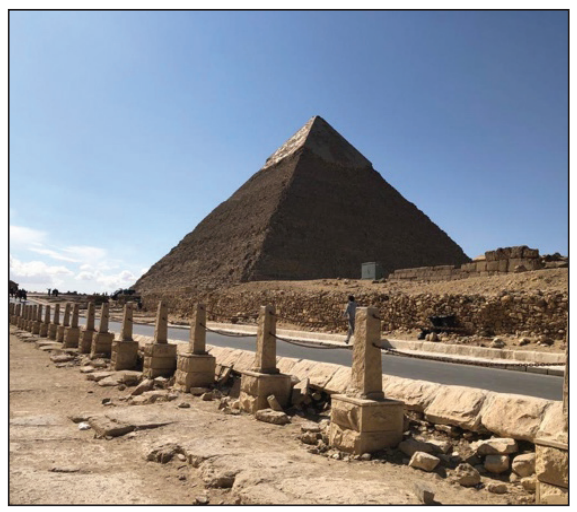

Giza'da Hafra Piramiti

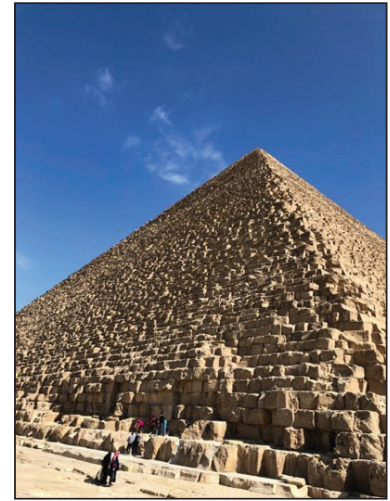

Giza'da Kufu Piramiti

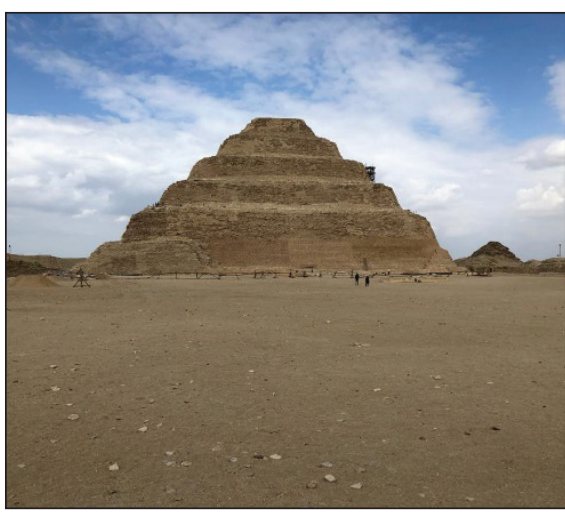

Sakkara'da Zoser Piramiti 